PRELIMINARY INTERPRETIVE REPORT 2006-1

\title{
EVIDENCE FOR GEOTHERMAL TUNGSTEN AND GERMANIUM MINERALIZATION IN EOCENE COAL AND ASSOCIATED SEDIMENTS, FORT HAMLIN HILLS AREA, INTERIOR, ALASKA
}

by

James C. Barker

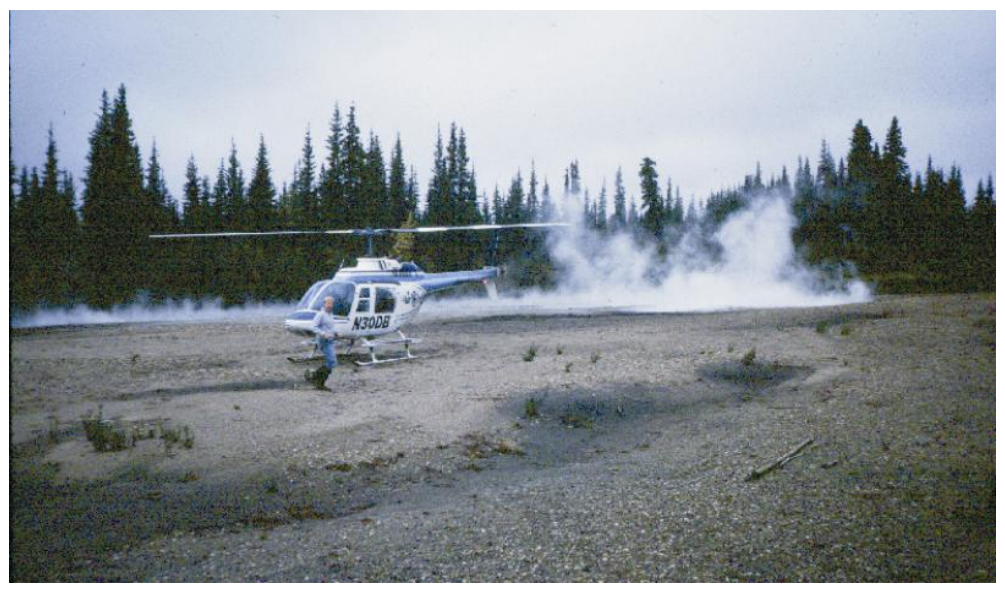

Geothermal spring (locality 'B,' figure 5, table 6) that, until now, has not been reported in any literature or maps.

April 2006

THIS REPORT HAS NOT BEEN REVIEWED FOR TECHNICAL CONTENT (EXCEPT AS NOTED IN TEXT) OR FOR CONFORMITY TO THE EDITORIAL STANDARDS OF DGGS.

\section{Released by}

STATE OF ALASKA

DEPARTMENT OF NATURAL RESOURCES

Division of Geological \& Geophysical Surveys

3354 College Rd.

Fairbanks, Alaska 99709-3707 



\section{TABLE OF CONTENTS}

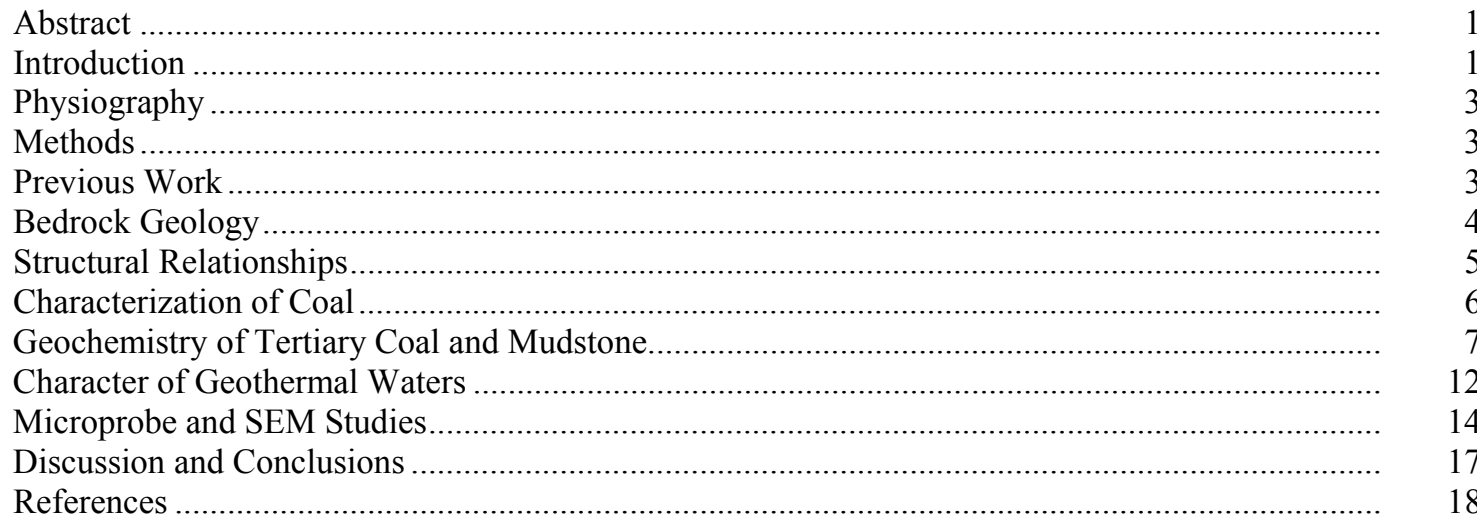

\section{FIGURES}

1. Geologic setting of the Fort Hamlin Hills area.................................................................. 2

2. Coal float is found on certain river bars of the Ray River.................................................. 4

3. Composite log of coal-bearing section at Coal Creek ......................................................... 5

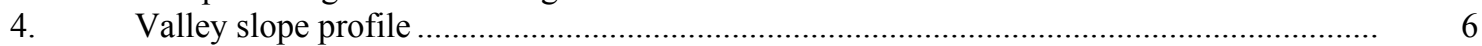

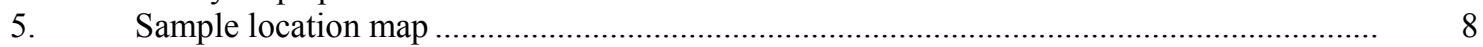

6. Data plot indicating an inverse relationship between percent ash and ppm tungsten........... $\quad 12$

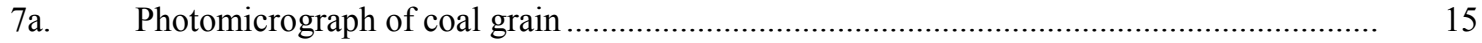

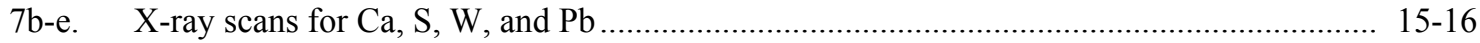

8. Sample showing a grain of FeS ................................................................................... 16

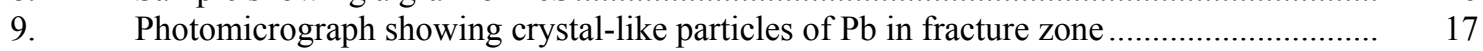

\section{TABLES}

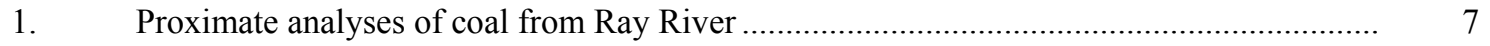

2. Trace element analyses of whole coal and coal ash from the Ray River basin .................... 9

3. Trace element analyses of coal ash from the Dall River basin ........................................... 10

4a. Trace metal concentrations in mudstone and tuffaceous sediments ...................................... 11

4b. Descriptions of mudstone and tuffaceous sediment samples........................................... 12

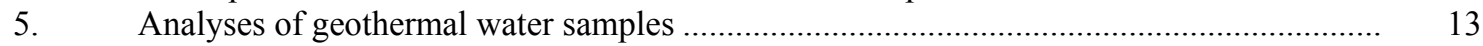

\section{APPENDICES}

A-1. Multi-element analyses by neutron activation of coal ash, Ray River coal samples ............ $\quad 20$

A-2. Multi-element analyses by neutron activation of coal ash, Dall River coal samples............ 21

B. Multi-element analyses by ICP of coal ash, Fort Hamlin Hills region .................................. 22

C. Multi-element analyses of geothermal water samples, Fort Hamlin Hills region ................. 23

D. Coordinates of sample locations................................................................................ 24 



\title{
EVIDENCE FOR GEOTHERMAL TUNGSTEN AND GERMANIUM MINERALIZATION IN EOCENE COAL AND ASSOCIATED SEDIMENTS, FORT HAMLIN HILLS AREA, INTERIOR, ALASKA
}

\author{
by \\ James C. Barker ${ }^{1}$
}

\begin{abstract}
Eocene-age coal and associated mudstones near the Fort Hamlin Hills in central interior Alaska are highly enriched in tungsten and other metals. Coal is found in small, semi-closed basins along the Ray River to the west of the Fort Hamlin Hills and the Dall River. Metals are most concentrated in calcium-rich coal ash; tungsten, germanium, and lead are each found to range as high as 1 percent or more. In addition, gold, gallium, and uranium are generally elevated, and most samples contain anomalous zirconium and rare-earth elements. Coal in the Fort Hamlin Hills area has an apparent rank of high-volatile, lignite A to subbituminous B, and generally has a 6-10 weight percent ash yield. Maceral composition is dominated by vitrinite.

Higher metal values occur in high-sulfur $(>1.4 \%)$ coals in the Ray River valley as compared to unmineralized low-sulfur $(<0.2 \%)$ coal in the neighboring Dall River valley. Mudstones that lie stratigraphically above the coal deposits in the Dall River valley generally contain 50 to $190 \mathrm{ppm}$ tungsten.

Microprobe studies suggest the mineralization found in coal of the Ray River mostly occurred in peat beds prior to, or concurrent with, diagenesis and coal formation. Mineralization is likely related to geothermal activity associated with rifting in a granitic terrane and volcanism. Water samples from present nearby hot springs contain anomalous levels of tungsten. Mineralization in peat accumulations or coal was likely accentuated due to Oligocene fissure basalts that entrapped the geothermal waters in the coal-forming section. Mudstones in the Dall River valley containing tungsten likely formed as Eocene-age lacustrine deposits in shallow lakes fed by geothermal water and intermittently covered by ash falls.
\end{abstract}

\section{INTRODUCTION}

The Fort Hamlin Hills region is located immediately north of the Yukon River, within the densely wooded rolling hills of northern Interior Alaska (fig. 1). The area is approximately $150 \mathrm{mi}(241 \mathrm{~km})$ northwest of Fairbanks via the Dalton Highway. The Alyeska Pipeline closely parallels the highway. While the study area extends from the bridge crossing the Yukon River north about $20 \mathrm{mi}(32 \mathrm{~km})$ to No Name Creek, most sampling was done along the Ray River, within $3 \mathrm{mi}(5 \mathrm{~km})$ of the Dalton Highway. It is densely vegetated and features very little bedrock exposure. Little was known of the geology prior to the pipeline construction in 1975-1977.

Investigations of mineral resources in the region, including this project, were conducted intermittently by the U.S. Bureau of Mines (USBM) between 1975 and 1989. This report, in process at the time of USBM's dissolution (1994), is one of a series of investigations to examine possible resources of strategic and critical minerals in Alaska.

Indications of high metal concentrations in coal ash were first detected in 1985 during a routine series of analyses of ash from various Alaskan coal deposits that are situated near or within metallogenic terranes. It was then decided to further investigate the unusual metal concentrations found in coal located in the Fort Hamlin Hills area.

Elsewhere in the world, the trace element content of coal ash has been studied as a possible future source of minerals. Although little is known relative to tungsten in coal, considerable attention has been given to germanium and uranium (Queneau and others, 1988). Some limited prototype production has occurred.

The following report benefited from the technical review contributed by several colleagues. The author is indebted to Gary Stricker, USGS, and Roger Burleigh and Robert Hoekzema, both formerly with the U.S. Bureau of Mines, for their critiques and helpful suggestions.

\footnotetext{
${ }^{1} 35940$ Highway 19, Kimberly, Oregon 97848. email: jcbarker@oregontrail.net
} 


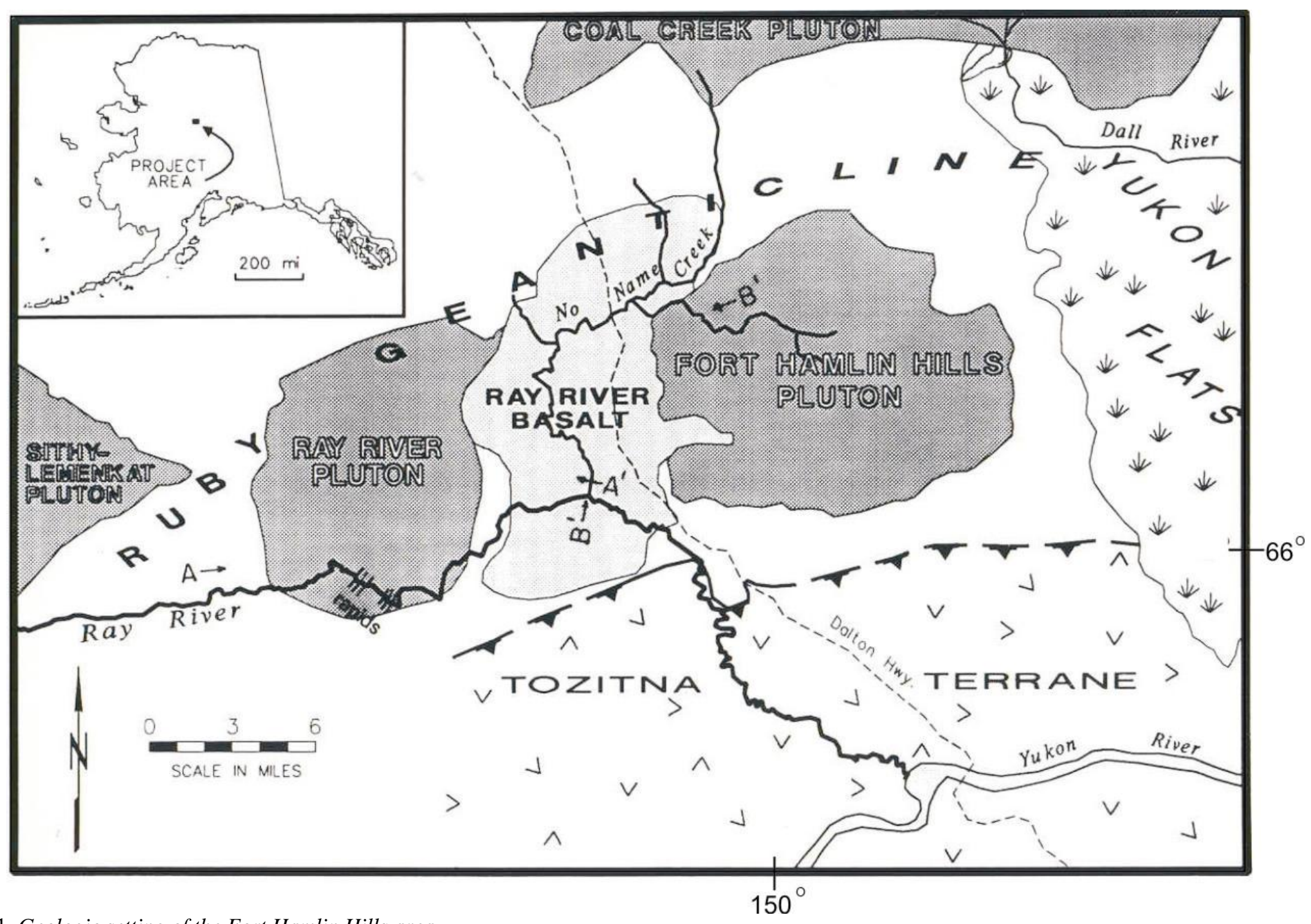

Figure 1. Geologic setting of the Fort Hamlin Hills area. 


\section{PHYSIOGRAPHY}

The Fort Hamlin Hills form a gently rolling upland, marginal to the Yukon Flats. Coal-bearing sediments are found in adjacent small, semi-closed basins. Generally, an escarpment is observed where the Yukon Flats joins the marginal slopes, suggesting that an equivalent section extending under the Yukon Flats has subsided perhaps as much as a hundred meters or more. Streams entering the basin have all cut V-shaped canyons into the escarpment.

The entire region is covered with continuous, unbroken vegetation of muskeg and tundra with thick growths of alder, willow, aspen, and spruce forest, with accompanying dense underbrush. Vegetative growth is extremely cyclic and climaxes with spruce, which ultimately supports summer forest fires, burning as much as hundreds of thousands of acres at a time and destroying coal outcrops.

The area is underlain by discontinuous permafrost, however, permafrost will nearly always be found in all terrains except under active principal water channels, larger lakes, and highest elevations. Pingos and thaw lakes are occasionally observed on the marginal upland slopes and in highland valleys where thick deposits of ice-rich, finegrained silt have accumulated.

The Fort Hamlin Hills and vicinity are within an intermontane region, noted for being one of the coldest (mean minimum January temperature of $-28^{\circ} \mathrm{F}\left[-33^{\circ} \mathrm{C}\right]$ at Fort Yukon), warmest (mean maximum July temperature of $76^{\circ} \mathrm{F}$ $\left.\left[24.5^{\circ} \mathrm{C}\right]\right)$, and one of the driest areas of Alaska, only receiving approximately 8 in $(20.3 \mathrm{~cm})$ of annual precipitation (Williams, 1962).

\section{METHODS}

The Fort Hamlin Hills coal project extended over 6 years, during which time additional elements were discovered to be present other than those sought in the original samples. Consequently, several different analytical procedures and laboratories were ultimately utilized for an expanded list of elements. Quantitative data given in the tables are footnoted as to the analytical procedure used. In addition, semi-quantitative, multi-element scans of coal ash and geothermal water are given in the appendices.

Mudstone and tuffaceous samples were collected as channel samples across specific stratigraphic intervals. However, due to the lack of outcrop, the coal samples had to be collected as chips taken from random pieces of float on some gravel bars of the Ray River (fig. 2). Only one coal bed was found in outcrop, located on Coal Creek. Coal samples from gravel bars were carefully broken apart and washed of any entrained sand prior to laboratory preparation. Care was taken to limit sample collection to only relatively fresh coal cobbles that had not yet dried and slacked due to air exposure. Samples were placed in sealed plastic bags to preserve contained moisture.

In the laboratory the coal samples were pulverized, weighed, and dried. Splits were made for whole-coal analyses, grain mounts, and ashing by high temperature ashing procedures (ASTM, 1979). Samples were heated at $750^{\circ} \mathrm{C}$ for up to $15 \mathrm{hrs}$ as necessary to produce $0.7-1.06 \mathrm{oz}(20-30 \mathrm{~g})$ of mineral ash.

In the field, geothermal water samples were tested for $\mathrm{pH}$, vacuum filtered at $0.4 \mu \mathrm{m}$, and collected in $16.9 \mathrm{oz}$. $(500 \mathrm{ml})$ sterile plastic bottles, then acidified ("fixed") with lab-grade nitric acid to avoid adsorption by the bottle walls.

\section{PREVIOUS WORK}

There is little information concerning trace element content in Alaskan coal, coal ash, or associated sediments. Rao (1968) reported on coals from the Alaska railbelt area and the North Slope, however, there were no samples from the Yukon River region. Among the elements Rao tested, elemental abundance for gallium, germanium, and lead in coal ash ranged from 19 to $48 \mathrm{ppm}, 8.5$ to $22 \mathrm{ppm}$, and 52 to $268 \mathrm{ppm}$, respectively. The coal was not analyzed for tungsten.

Coal occurrences in the Yukon Flats region, including the Fort Hamlin Hills area, are described and characterized by Barker (1981) and Barker and Goff (1986), however, no data on trace element values in coal ash were included. The 1981 report gave analytical data reporting anomalous tungsten values in mudstones in the Dall River valley located on the east side of the Fort Hamlin Hills and suggested possible similarities to Searles Lake, $\mathrm{CA}$, where tungsten is associated with evaporitic sodium carbonate brine and lakebed mud. Sodium carbonate (trona) occurs on summer-time dry lakebeds along a northeast trend across the Yukon Flats (Barker, 1981; Clautice and Mowatt, 1981), beginning about $30 \mathrm{mi}(48 \mathrm{~km})$ east of the project area. The source of the trona deposits is presently unknown.

Regional mapping relevant to Tertiary through present geology in the region is compiled by Williams (1962). Geologic mapping at 1:63,360 scale specific to the Fort Hamlin Hills area was more recently completed by Barker (1991) in conjunction with assessment of tin placer potential in the Ray River watershed. 


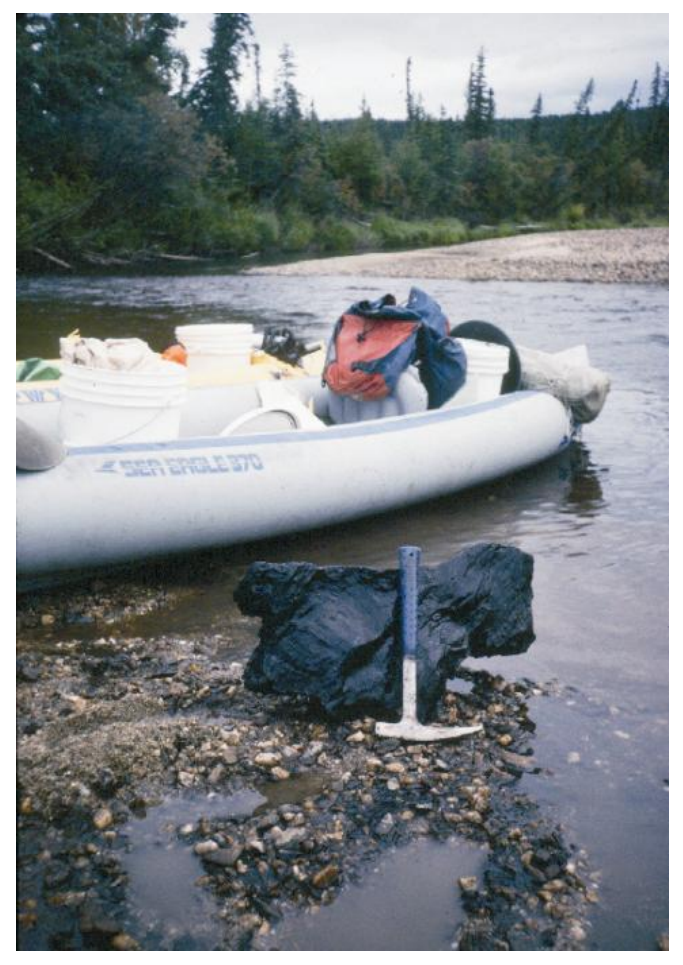

Figure 2. Coal float found on certain river bars of the Ray River

\section{BEDROCK GEOLOGY}

The Fort Hamlin Hills area includes several granitic plutons that intrude Paleozoic schist, phyllite, quartzite, greenstone, and limestone along the southeast flank of the Ruby Geanticline (fig. 1). The geanticline forms a broad northeast-trending belt of crystalline rock in north-central Alaska (Arth and others, 1989), which, near the Fort Hamlin Hills, is flanked on the south by north-thrusted rocks of the Tozitna Terrane (fig. 1).

As elsewhere in the Interior, bedrock exposure is scarce. The oldest rocks of the Ruby Geanticline are quartzmica schist, light-colored quartzite, and phyllite, which exhibit thermal alteration in the vicinity of the granitic intrusions (fig. 1). These rocks are overlain by a younger Paleozoic quartzite and limestone unit that is altered to marble and calc-silicate rock near the plutonic contacts.

Granitic rocks (Kg) (fig. 1) generally underlie the higher terrain and may be continuous at shallow depth. They are separated from each other by approximately flat-lying flows of fissure basalt and Tertiary sedimentary rock, preserved in obscure graben-like basins. Major oxide analyses indicate the plutons are peraluminous calc-alkaline granite (Barker, 1991). The Fort Hamlin Hills, Sithylemenkat, Ray River, and Coal Creek plutons are considered to be among more than a dozen similar Cretaceous-age (105-115 ma) plutons in the Ruby batholith (Arth and others, 1989).

Tertiary-age, coal-bearing sedimentary rocks (Ts) include shale, tuffaceous mudstone with ash beds and tuff, arkosic sandstone and conglomerate, and lignitic coal. Mudstones and arenites generally contain carbonized plant fragments, and fossilized resin is common in coal. Regressive weathering of the Tertiary rock and particularly the susceptibility of coal to forest fires limit exposure of the Tertiary unit to only a few outcrops, however, pieces of coal float on gravel bars of the downcutting Ray and Dall Rivers suggest that Tertiary rocks underlie much of the valley floors.

The Tertiary-age rocks were largely deposited during the early- to mid-Tertiary. Interpretation of sparse outcrops suggests sedimentation was originally high-energy fluvial gravel that evolved into lower-energy finegrained sediment deposition in lakebeds and peat bogs, which were cut by meander channels and intermittently covered by ash falls (fig. 3). The older Tertiary sediments are upward-fining sequences of well-rounded, quartzpebble conglomerate and sandstone that are best exposed at Lat $66^{\circ} 02^{\prime}$, Long $150^{\circ} 16^{\prime}$, and also seen along Coal Creek. Possibly younger Tertiary rocks are exposed near Lake 392 (Lat $66^{\circ} 00.5^{\prime}$, Long $150^{\circ} 10^{\prime}$ ), where a bedrock knob is composed of arkosic conglomerate and shale. The youngest Tertiary section in the Ray River valley is exposed in an outcrop $2 \mathrm{mi}(3.2 \mathrm{~km})$ upstream of the mouth of No Name Creek, where a 50-ft-thick (15-m-thick) sequence of coaly volcanic ash and mudstone, carbon-rich volcaniclastic rock, coal, arkosic (granitic) sands, and 
semi-consolidated, white-weathering fluvial gravels are overlain by basalt. On Coal Creek, alternating beds of mudstone and water-lain tuff overlie an 18-ft-thick (5.5-m-thick) coal bed. A K-Ar age determination on an ash bed in this section gave an Eocene date of $38.6 \pm 1.6$ ma (fig. 3; Barker, 1981).

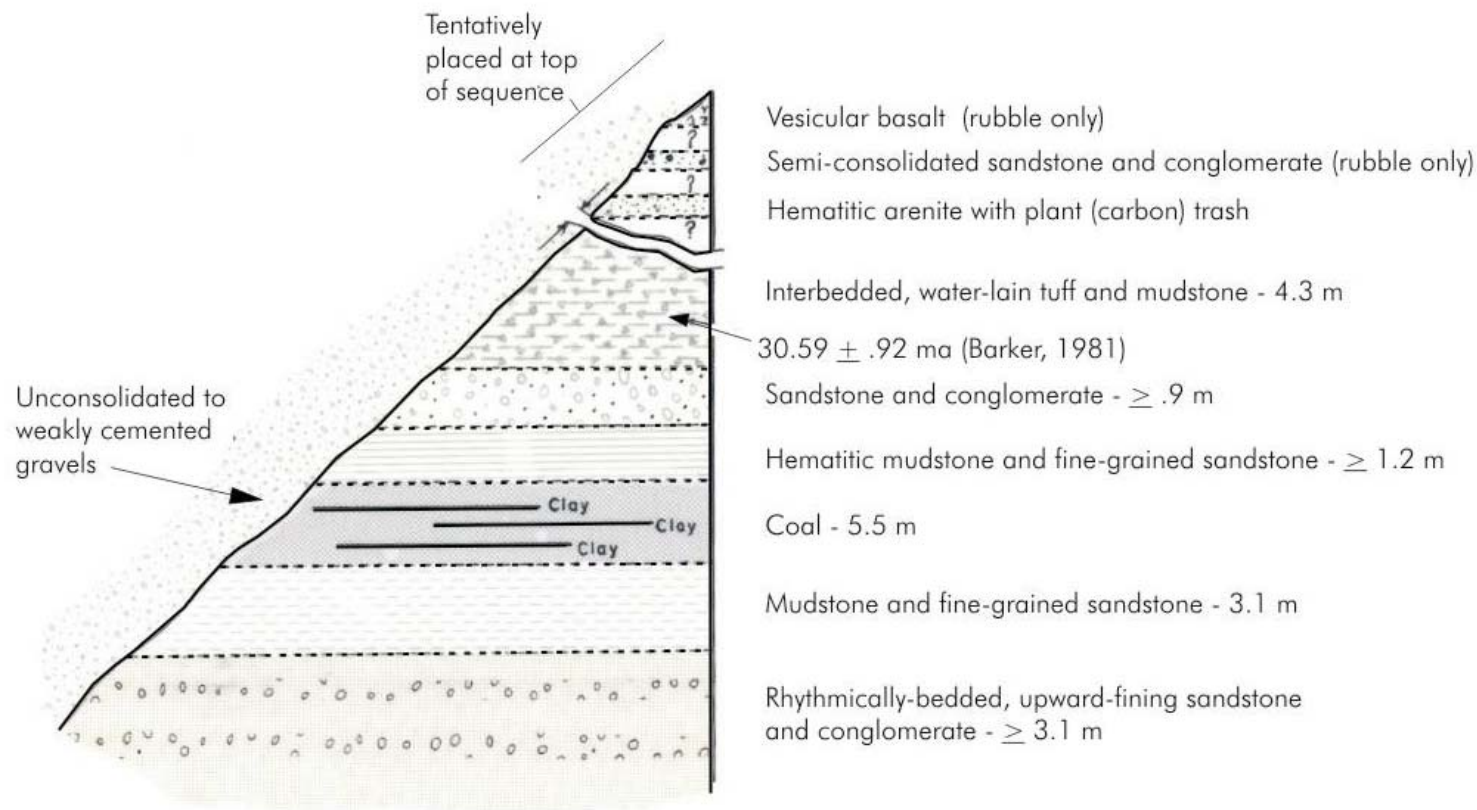

Figure 3. Composite section of coal-bearing rocks at Coal Creek.

Tertiary basalt lavas (fig. 4) form the youngest bedrock unit and are inferred to cover about 60 square mi (155 square $\mathrm{km}$ ) of the Ray River drainage and a smaller area on the Dall River. Both the Ray and Dall rivers have breached the basalt flows and cut into the underlying pre-Tertiary rock units. Texture of the basaltic rock ranges from vesicular to massive, and compositions vary from olivine basalt to andesite. Vesicles are locally filled with calcite, quartz, or native sulfur. At the outcrop on the Ray River, $2 \mathrm{mi}(3.2 \mathrm{~km})$ upstream of No Name Creek, at least three flows of columnar jointed basalt are stacked together. The total section of basaltic flows is about $200 \mathrm{ft}(65 \mathrm{~m})$ thick, flat lying, and lies between 475 and $725 \mathrm{ft}(150$ and $235 \mathrm{~m})$ in elevation.

Albanese (1987), who examined a basalt flow exposure in a road cut $3 \mathrm{mi}(4.8 \mathrm{~km})$ south of No Name Creek, suggested a tholeiitic or alkaline affinity comparable to basalts from extensional systems. The flows near No Name Creek, for which an age determination by K-Ar methods reported an Oligocene date of $30.59 \pm 0.92$ ma (Albanese, 1987), have no exposed source.

\section{STRUCTURAL RELATIONSHIPS}

The project area is included in the Ruby Geanticline crystalline terrane (Arth and others, 1989). Mafic volcanic rock, gabbro, and chert of the Tozitna Terrane abut the Ray River area to the south along a poorly exposed overthrust boundary (fig. 1). Evidence of this nearly flat-lying thrust fault can be viewed where the fault crosses the Ray River, where Jurassic andesite lies in fault contact on Paleozoic phyllites.

The Tertiary coal-bearing rocks have been structurally disrupted by apparent dip-slip faulting that has created a series of small, obscure, graben-like, stepped basins containing the Tertiary rocks. An example of a dip-slip fault contact between the basalt and older Tertiary sediments is visible in the outcrop $2 \mathrm{mi}(3.4 \mathrm{~km})$ above the mouth of No Name Creek, and others can be inferred from aerial photography. Consequently, the coal-bearing unit is found at decreasing elevations toward the center of graben-like features between the plutons (fig. 4). Each of these basins contains Tertiary coal-bearing rock near, or below, the elevation of the valley floor as indicated by local concentrations of coal rubble only on gravel bars. An interpretive cross-section shown in fig. 4 demonstrates the structural relationships as viewed along the valleys of No Name Creek and the Ray River. In the intervening area between the Fort Hamlin and Ray River plutons, Tertiary rock or rubble occurs in basins at progressively lower 
elevations of 425, 400, and $375 \mathrm{ft}(140,130$, and $120 \mathrm{~m})$. Coal is also found on gravel bars at $625 \mathrm{ft}(200 \mathrm{~m})$ immediately west of the Ray River pluton and at $350 \mathrm{ft}(115 \mathrm{~m})$ near the Tozitna Terrane overthrust.

Much of the inferred extent of Ts is, or was formerly, overlain by basalt flows. The base of the Tertiary basalt flows could only be examined in the previously mentioned Ray River outcrop, where it overlies Tertiary coaly sediments and exhibits a carbonaceous contaminated basal zone. A quenched fracture stockwork, including thin $(0.1$ in, $2 \mathrm{~mm}$ ) selvages of obsidian and traces of phosphate staining, occurs at the river level and signifies the abrupt end of organic accumulation in a wet peat bog.

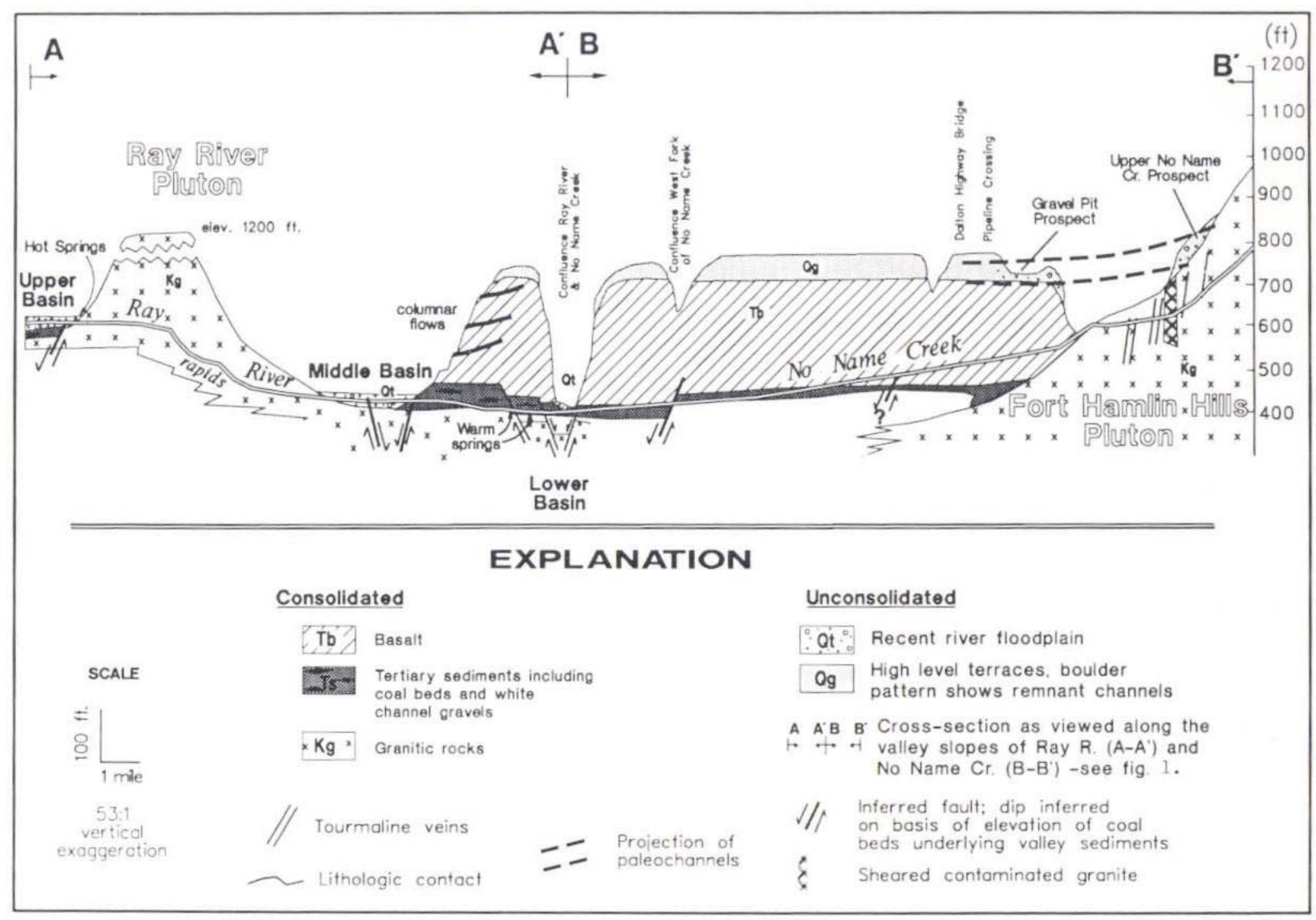

Figure 4. Valley slope profile.

\section{CHARACTERIZATION OF COAL}

Coal occurrences in the Ray and Dall River basins are characterized by Barker (1981). Coal samples collected during this project were submitted to the University of Alaska, Mineral Industry Research Laboratory (MIRL), Dr. P.D. Rao, Supervisor, for standard ASTM tests and analyses as specified and reported in the following tables and polished section petrography. Most samples examined are bright, subbituminous vitreous coal that breaks with a concoidal fracture; other pieces of coal are dull black to dark gray due to high ash content. Apparent rank of coal in the Fort Hamlin Hills area is similar to, or higher than, elsewhere in Interior Alaska (Merritt and Hawley, 1986) and varies from lignite A to subbituminous B, with heating value generally between 9,000 and 12,000 Btu on a moisturefree basis (table 1). Reflectance tests usually give values of 0.33 to 0.45 . In polished sections, coal specimens appear to be largely vitrinite with small irregular areas and broken fragments of cellular fusinite. Isolated masses of macrinite indicate drier woody source material.

Ash yield by weight of most coal samples is 6-10 percent, however, some coal specimens were found to contain much higher levels of ash, up to 40 percent (e.g., sample location 13 with 20 percent ash, table 1). A few specimens were found with interbedded black vitreous, low-ash coal, and dull gray-black, high-ash coal. 
The Dall River coal is lower in sulfur than coal found along the Ray River. Typical of most Alaskan coal (Merritt and Hawley, 1986), the Dall River coal deposits contain 0.22-0.24 percent total sulfur (three samples tested, Barker, 1981). Six Ray River samples tested for sulfur show a marked contrast (table 1, fig. 5) and, although they are similar in other measured parameters, total sulfur ranges from 1 to 2 percent on a moisture-free basis.

Table 1. Proximate analyses ${ }^{1}$ of coal from Ray River.

\begin{tabular}{|c|c|c|c|c|c|c|c|c||}
\hline $\begin{array}{c}\text { Sample } \\
\text { Number }\end{array}$ & $\begin{array}{c}\text { Map } \\
\text { Location } \\
\text { Number }\end{array}$ & Basis & $\begin{array}{c}\text { Moisture, } \\
\%\end{array}$ & Ash, \% & $\begin{array}{c}\text { Volatile } \\
\text { Matter, \% }\end{array}$ & $\begin{array}{c}\text { Fixed } \\
\text { Carbon, } \\
\%\end{array}$ & $\begin{array}{c}\text { Heating } \\
\text { Value, } \\
\text { BTU/lb }\end{array}$ & $\begin{array}{c}\text { Total } \\
\text { Sulfur }\end{array}$ \\
\hline \hline RM24723 & 16 & 1 & 27.47 & 2.41 & 36.08 & 34.05 & 9049 & 1.31 \\
\hline & & 2 & & 3.32 & 49.74 & 46.94 & 12476 & 1.80 \\
\hline & & 3 & & & 51.45 & 48.55 & 12904 & 1.86 \\
\hline RM24727 & 18 & 1 & 27.94 & 4.74 & 35.53 & 31.79 & 8539 & 1.05 \\
\hline & & 2 & & 6.57 & 49.31 & 44.12 & 11851 & 1.46 \\
\hline & & 3 & & & 52.78 & 47.22 & 12684 & 1.56 \\
\hline RM24726 & 19 & 1 & 26.49 & 7.00 & 33.64 & 32.87 & 8033 & 1.49 \\
\hline & & 2 & & 9.52 & 45.76 & 44.72 & 10928 & 2.02 \\
\hline & & 3 & & & 50.58 & 49.42 & 12078 & 2.24 \\
\hline RM24725 & 20 & 1 & 26.91 & 7.25 & 33.87 & 31.97 & 7807 & 1.05 \\
\hline & & 2 & & 9.92 & 46.34 & 43.74 & 10679 & 1.43 \\
\hline & & 3 & & & 51.44 & 48.56 & 11857 & 1.59 \\
\hline PB10386 & 7 & 1 & -- & -- & -- & -- & -- & -- \\
\hline & & 2 & & 10.49 & 43.87 & 45.64 & 10371 & 1.54 \\
\hline & & 3 & & & 49.01 & 50.99 & 11598 & 1.72 \\
\hline PB10384 & 13 & 1 & -- & -- & -- & -- & -- & -- \\
\hline & & 2 & & 20.39 & 24.81 & 54.80 & 9403 & 1.11 \\
\hline & & 3 & & & 31.17 & 68.83 & 11823 & 1.39 \\
\hline
\end{tabular}

Basis Legend: $\quad 1=$ as received

$2=$ moisture free

$3=$ dry, ash free

$--=$ not analyzed

${ }^{1}$ Proximate analyses of coal determined by University of Alaska Mineral Industries Research Laboratory, using standard ASTM testing procedures

\section{GEOCHEMISTRY OF TERITARY COAL AND MUDSTONE}

Valkovic (1983) noted that elemental concentrations in coal reflect the elemental composition of the coalforming material, properties of the depositional environment, and processes that were active during the coal-forming period. The abnormal metal concentrations found in the Fort Hamlin Hills area reflect metal uptake by either live vegetative material or at some point during the coal-forming period (tables 2 and 3, appendices A and B). Ash prepared from coal samples collected as float in the Ray River streambed can also be characterized as high calcium ( $>10$ percent $\mathrm{Ca}$, appendix $\mathrm{B}$ ).

Mudstones in the Dall River vicinity and at least one site in the Ray River valley are notably manganese stained and radioactive (200-400 cps relative to a background of about $50 \mathrm{cps}$ ). Manganese content ranges from 1,000 to 4,000 ppm (table 4). Uranium content up to $50 \mathrm{ppm}$ accounts for the observed radioactivity (Barker, 1981). In the Dall River valley, mudstone intervals can be readily distinguished from tuff beds by the latter's lower radiometric response. No discrete uranium minerals could be distinguished by X-ray diffraction. 


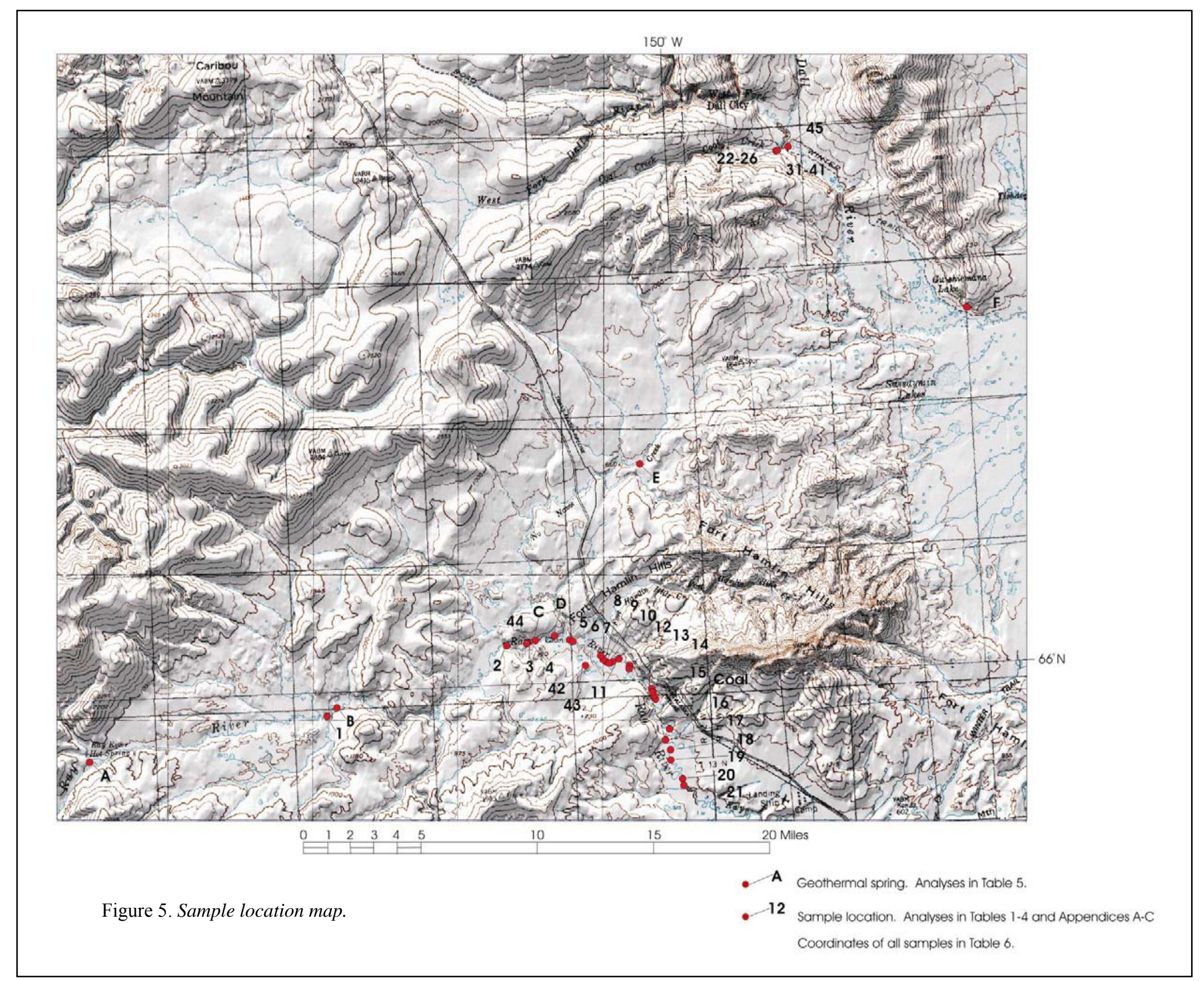


Table 2. Trace element analyses (in ppm) of whole coal and coal ash from the Ray River basin.

\begin{tabular}{|c|c|c|c|c|c|c|c|c|c|c|c|c|}
\hline \multirow{2}{*}{$\begin{array}{c}\text { Map } \\
\text { Location } \\
\text { Number } \\
\end{array}$} & \multirow{2}{*}{$\begin{array}{l}\text { Sample } \\
\text { Number }\end{array}$} & \multicolumn{6}{|c|}{ Coal Ash $^{1}$} & \multicolumn{5}{|c|}{ Whole Coal } \\
\hline & & $\%$ Ash & W & $\mathrm{Pb}^{2}$ & $\mathrm{U}^{3}$ & $\mathrm{Ga}$ & Ge & $\mathrm{W}^{4}$ & $\mathrm{~Pb}^{4}$ & $\mathrm{U}^{3}$ & $\mathrm{Ga}$ & $\mathrm{Ge}^{2}$ \\
\hline 1 & RM26004 & 14.68 & $2,300^{4}$ & 332 & $3,090^{5}$ & $820^{2}$ & $12,200^{6}$ & -- & 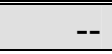 & 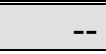 & 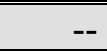 & - \\
\hline 2 & RM26097 & 5.95 & $11,000^{6}$ & 248 & $94^{5}$ & $70^{2}$ & $700^{2}$ & 375 & 17 & 5.4 & -- & 50 \\
\hline 3 & RM27598 & -- & $1,000^{4}$ & 325 & 155 & -- & $<5^{2}$ & 175 & 79 & 46.8 & -- & $<5$ \\
\hline 4 & RM25739 & -- & $1,900^{3}$ & -- & -- & -- & -- & 26 & -- & 13.0 & -- & $<10$ \\
\hline 5 & RM25445 & 6.70 & $3,790^{5}$ & 375 & 322 & -- & $322^{7}$ & -- & -- & -- & -- & -- \\
\hline 6 & RM25446 & 8.70 & $2,730^{5}$ & 255 & 171 & -- & $1,433^{7}$ & -- & -- & -- & -- & -- \\
\hline 7 & PB10386 & 9.00 & $3,420^{3}$ & -- & 467 & -- & $<310^{3}$ & -- & -- & -- & -- & -- \\
\hline 8 & RM26098 & 10.09 & $7,400^{4}$ & 120 & $450^{5}$ & $110^{2}$ & $300^{2}$ & 325 & 16 & 35.3 & -- & 20 \\
\hline 9 & RM25447 & 8.10 & $5,190^{5}$ & 970 & 311 & -- & $143^{7}$ & -- & -- & -- & -- & -- \\
\hline 10 & $\mathrm{RM} 25448$ & 15.90 & $1,660^{5}$ & $18,800^{6}$ & 299 & -- & $108^{7}$ & -- & -- & -- & -- & -- \\
\hline 11 & RM27560 & -- & -- & -- & -- & -- & -- & 90 & 28 & 28.2 & -- & 70 \\
\hline 12 & RM25449 & 39.10 & $424^{5}$ & 1,000 & 147 & -- & $48^{7}$ & -- & -- & -- & -- & -- \\
\hline 13 & PB10384 & 18.00 & $85^{3}$ & -- & 78 & -- & $<230^{3}$ & -- & -- & -- & -- & -- \\
\hline 14 & RM25450 & 6.20 & $308^{5}$ & 5,400 & 44 & -- & $18^{7}$ & -- & -- & -- & -- & -- \\
\hline 15 & RM26358 & 6.38 & $3,700^{4}$ & 54 & $52^{7}$ & $92^{2}$ & $140^{2}$ & 65 & 12 & 4.5 & -- & 30 \\
\hline 16 & RM24723 & 3.32 & $19,400^{4}$ & 133 & -- & $53^{7}$ & $\mathrm{IS}^{8}$ & -- & -- & -- & -- & -- \\
\hline 17 & RM27563 & -- & $3,690^{6}$ & -- & -- & -- & -- & 125 & 8 & 15.7 & -- & 70 \\
\hline 18 & RM24727 & 6.57 & $14,900^{4}$ & 50 & -- & $137^{7}$ & $900^{6,8}$ & -- & -- & -- & -- & -- \\
\hline 19 & RM24726 & 9.52 & $5,500^{4}$ & 554 & -- & $181^{8}$ & $100^{6,8}$ & -- & -- & -- & -- & -- \\
\hline 20 & RM24725 & 9.92 & $1,900^{7}$ & $<2$ & -- & $133^{8}$ & $<100^{6,8}$ & -- & -- & -- & -- & -- \\
\hline 21 & RM27564 & -- & $7,130^{6}$ & -- & -- & -- & -- & 275 & 10 & 27.7 & -- & 150 \\
\hline
\end{tabular}

IS = insufficient sample material -- = not analyzed
1 percent ash determined on moisture-free basis

2 analyzed by atomic absorption spectrography

3 analyzed by neutron activation

4 analyzed by colorimetric procedure
5 analyzed by $\mathrm{x}$-ray fluorimetric procedure

6 assay by chemical extractions

7 analyzed by inductively coupled plasma procedure

8 analyzed by DC plasma emission 
Table 3. Trace element analyses (in ppm) of coal ash from the Dall River basin.

\begin{tabular}{|c|r|r|r|r|r|r|r||}
\hline $\begin{array}{c}\text { Map } \\
\text { Location } \\
\text { Number }\end{array}$ & $\begin{array}{c}\text { Sample } \\
\text { Number }\end{array}$ & $\% \mathrm{Ash}^{1}$ & $\mathrm{~W}^{2}$ & $\mathrm{~Pb}^{3}$ & $\mathrm{U}^{2}$ & $\mathrm{Ga}$ & $\mathrm{Ge}^{4}$ \\
\hline \hline 22 & HZ25636 & 5.52 & 205 & 280 & 29.5 & -- & $<10$ \\
\hline 23 & HZ25638 & -- & 9 & 350 & 71.9 & -- & $<10$ \\
\hline 24 & HZ25639 & -- & 23 & 200 & 30.2 & -- & $<10$ \\
\hline 25 & HZ25641 & 5.22 & 18 & 310 & 6.6 & -- & 24 \\
\hline 26 & HZ25642 & 18.87 & 210 & 280 & 7.7 & -- & 38 \\
\hline
\end{tabular}

$--=$ not analyzed

${ }_{2}^{1}$ percent ash determined on moisture-free basis

2 analyzed by neutron activation

${ }^{3}$ analyzed by atomic absorption spectrography

${ }^{4}$ analyzed by inductively coupled plasma procedure

The mudstone is interbedded with units of water-lain tuffs, generally 0.1 to $1.0 \mathrm{ft}(3.5$ to $30.5 \mathrm{~cm})$ thick. The rocks are phosphatic; a mudstone sample analyzed for major oxides contained 1.60 percent $\mathrm{P}_{2} \mathrm{O}_{5}$ and 3.1 percent $\mathrm{CaO}$ (Barker, 1981, sample HZ10272), and similar rocks in the Hodzana River valley, $40 \mathrm{mi}(64 \mathrm{~km})$ to the east, contain spheroids of vivianite $\left[\mathrm{Fe}_{3}\left(\mathrm{PO}_{4}\right)_{2} \cdot 8 \mathrm{H}_{2} \mathrm{O}\right]$ and bedded zeolite. Mudstone near the Dall River is also cut by 0.04-in-thick (1-mm-thick) veinlets containing hydroxylapatite $\left[\mathrm{Ca}_{5}\left(\mathrm{PO}_{4}\right)_{3}(\mathrm{OH})\right]^{2}$

Mineralized coal was found only in the Ray River valley. Because coal does not outcrop, it is not possible to evaluate correlation of metal content to coal stratigraphy. Analytical results from 21 samples of Ray River coal (table 2 and appendices A and B) demonstrate that while tungsten and, to a lesser extent, germanium are highly concentrated in most samples, other metals (rare earth elements, gold, yttrium, zirconium) are more variable and may suggest vertical zonation or some local concentration phenomena.

Concentration of tungsten in coal ash shows no positive correlations to the mineral matter in the coal. Percent ash is inversely related to the tungsten content in the coal (fig. 6). Studies elsewhere have shown metal values in coal concentrate in the macerals (vitrinite), not in the inorganic mineral material (Eskenazy, 1982; Queneau and others, 1988). In the Fort Hamlin Hills area, coal samples that are diluted with abundant ash contain correspondingly less organic material and consequently have lower metal values.

Other elements appear to be horizontally zoned at a larger scale. For instance, lead is strongly present in samples in the upstream portion of the Ray River valley.

\footnotetext{
${ }^{2}$ Analyses by X-ray diffraction, Nam Veach, Alaska Division of Geological \& Geophysical Surveys
} 
Table 4a. Trace metal concentrations in mudstone and tuffaceous sediments.

\begin{tabular}{|c|c|c|c|c|c|c|c|c|c|c|c|c|c|c|}
\hline \multirow{2}{*}{$\begin{array}{c}\text { Map } \\
\text { Location } \\
\text { Number }\end{array}$} & \multirow{2}{*}{$\begin{array}{l}\text { Sample } \\
\text { Number }\end{array}$} & \multicolumn{13}{|c|}{ Analyses $^{1}, \mathrm{ppm}$} \\
\hline & & $\mathrm{Au}$ & As & $\mathrm{Ba}$ & $\mathrm{La}$ & $\mathrm{Ce}$ & Mo & $\mathrm{Mn}$ & $\mathrm{Sm}$ & W & $\mathrm{U}$ & $\mathrm{Zn}$ & $\mathrm{Zr}$ & $\mathrm{Y}$ \\
\hline 31 & HZ25647 & $\mathrm{L}$ & 52 & 400 & 75 & 180 & 8 & -- & 14 & 190 & 23 & $\mathrm{~L}$ & 700 & $60^{2}$ \\
\hline 32 & HZ25643 & $\mathrm{L}$ & 42 & 770 & 58 & 160 & 4 & -- & 10 & 64 & 14 & $\mathrm{~L}$ & $\mathrm{~L}$ & $39^{2}$ \\
\hline 33 & HZ15530 & -- & 43 & 5,841 & 12 & 23 & -- & 760 & 3 & 94 & 5 & -- & 243 & -- \\
\hline 34 & HZ15529 & -- & 58 & $\mathrm{~L}$ & 73 & 173 & -- & 4,159 & 16 & 105 & 25 & 284 & 170 & -- \\
\hline 35 & HZ15531a & $\mathrm{L}$ & 51 & 490 & 76 & 260 & 9 & -- & 14 & 69 & 31 & $\mathrm{~L}$ & $\mathrm{~L}$ & $66^{2}$ \\
\hline 36 & $\mathrm{HZ15531b}$ & -- & 71 & $\mathrm{~L}$ & 85 & 221 & -- & 3,566 & 19 & 73 & 30 & $\mathrm{~L}$ & 161 & -- \\
\hline 37 & HZ15535 & $\mathrm{L}$ & 52 & 620 & 64 & 180 & -- & -- & 14 & 51 & 30 & $\mathrm{~L}$ & $\mathrm{~L}$ & $51^{2}$ \\
\hline 38 & HZ15533 & -- & 97 & 742 & 78 & 163 & -- & 1,581 & 14 & 68 & 28 & 233 & 168 & -- \\
\hline 39 & HZ15536 & -- & 30 & 234 & 31 & 68 & -- & -- & 5 & $\mathrm{~L}$ & 6 & $\mathrm{~L}$ & 86 & -- \\
\hline 40 & HZ25637 & $\mathrm{L}$ & 118 & 370 & 8 & 21 & 3 & -- & 2.6 & $\mathrm{~L}$ & 4 & $\mathrm{~L}$ & $\mathrm{~L}$ & $\mathrm{~L}^{2}$ \\
\hline 41 & HZ15578 & $\mathrm{L}$ & 27 & 5,200 & 211 & 290 & $\mathrm{~L}$ & -- & 35 & 130 & 16 & $\mathrm{~L}$ & 890 & -- \\
\hline 42 & RM27184 & -- & -- & -- & 60 & -- & -- & -- & - & 18 & 13 & -- & -- & -- \\
\hline 43 & RM27559 & -- & -- & -- & -- & -- & -- & 1,400 & -- & $60^{2}$ & 23 & -- & -- & -- \\
\hline 44 & RM26038 & $\mathrm{L}$ & -- & -- & -- & -- & -- & -- & -- & $140^{2}$ & 6 & -- & -- & 33 \\
\hline 45 & HZ15576 & -- & 87 & $\mathrm{~L}$ & 89 & 174 & -- & 4,197 & 18 & 105 & 26 & 288 & 167 & -- \\
\hline \multicolumn{2}{|c|}{ Detection Limit } & .005 & 1 & 100 & 5 & 10 & 2 & 100 & 0.1 & 2 & 0.5 & 100 & 10 & 1 \\
\hline
\end{tabular}

${ }^{1}$ analyses by neutron activation procedure, except $\mathrm{Y}$ by inductively coupled plasma or as otherwise noted

2 analyses by $x$-ray fluorescence

-- not analyzed

L less than detection limit; lower limits are matrix affected and may be higher in specific samples 
Table 4b. Descriptions of mudstone and tuffaceous sediment samples.

\begin{tabular}{|c|l||}
\hline $\begin{array}{c}\text { Map } \\
\text { Location } \\
\text { Number }\end{array}$ & \multicolumn{1}{|c|}{ Description } \\
\hline \hline $31-41$ & $\begin{array}{l}\text { See figure 3, Dall River area; samples 31-39 are from individual mudstone beds from the } \\
\text { "interbedded, water lain tuff and mudstone" unit. Samples 40 \& 41 are from mudstone } \\
\text { rubble of unknown position in the section. }\end{array}$ \\
\hline 42 & Mudstone rubble in slump, Ray River area, near Lake 392. \\
\hline 43 & $\begin{array}{l}\text { Thermally altered and brittle laminated shale, volcanic rubble nearby, Ray River area, } \\
\text { near Lake 392. }\end{array}$ \\
\hline 44 & $\begin{array}{l}\text { Coarse-grain composition of angular pyroclastics, quartz pebbles, and soft tar-like } \\
\text { carbonaceous matter, Ray River 2 miles upstream of No Name Creek. }\end{array}$ \\
\hline 45 & Grab sample mudstone, confluence of Coal Creek and Ray River. \\
\hline
\end{tabular}

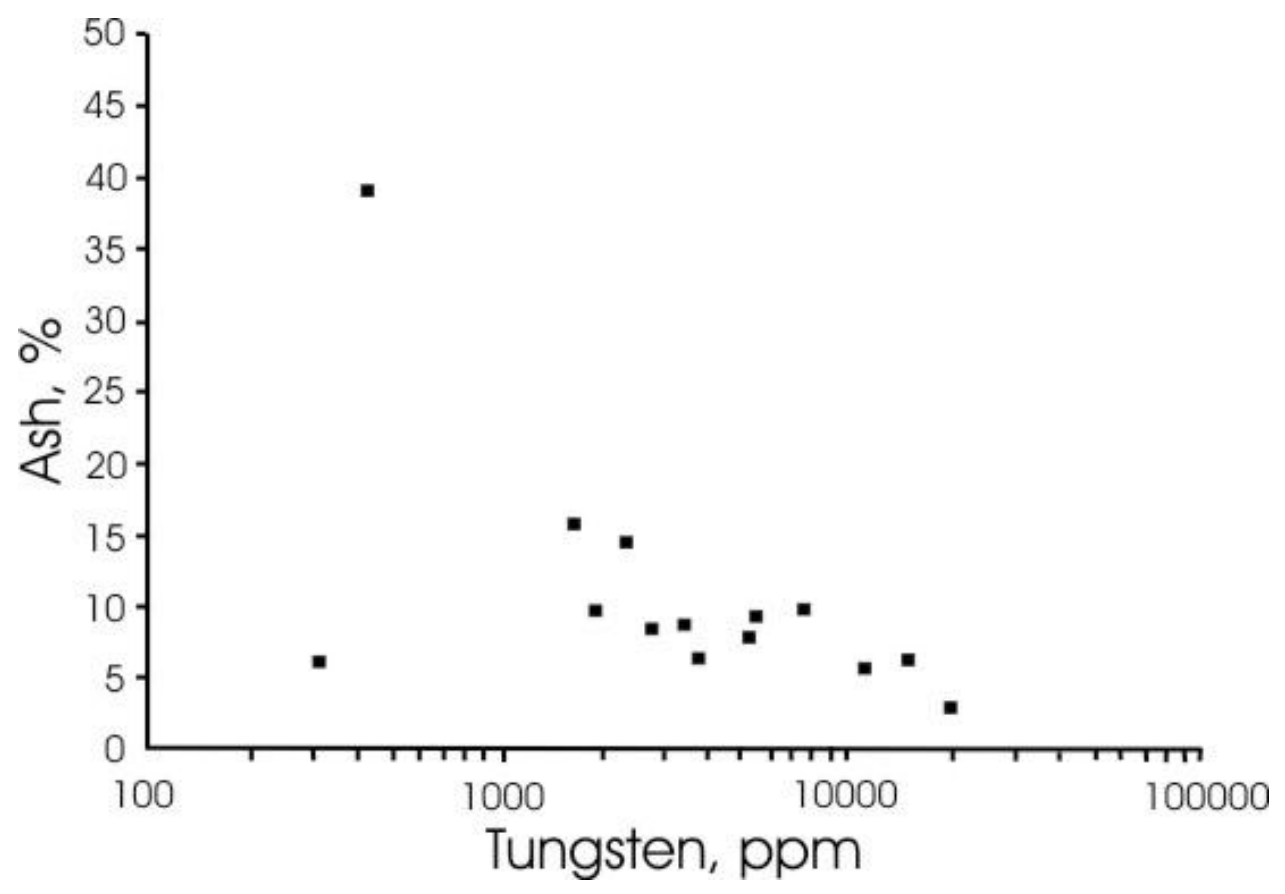

Figure 6. Plot indicating an inverse relationship between ash and tungsten.

\section{CHARACTER OF GEOTHERMAL WATERS}

A northeast alignment of six geothermal seeps and springs occurs in the Fort Hamlin Hills area (fig. 5); farther to the west, hot springs at Kilolitna and Istahlana also align with this trend. Five of the sites were sampled to determine if tungsten, lead, uranium, and possibly other metals are contained as mobile metal ions in geothermal waters $^{3}$. Geothermal site E (fig. 5) had insufficient flow to permit collection of a non-turbid sample, so no sample

\footnotetext{
${ }^{3}$ Samples from map locations A, F-1, and F-2 were provided by S. Liss, Alaska Division of Geological \& Geophysical Surveys
} 
was collected. Analytical data for tungsten, lead, and uranium are given in table 5, and multi-element analyses are included as Appendix C. Spring waters are basic (pH 8 to 9) and contain minor concentrations of alkali metals.

Very little is published regarding concentration of tungsten in natural waters. Ground waters from siliceous igneous rocks generally are relatively low in mineral content. Hall and others (1988) studied the tungsten and molybdenum content of natural spring waters (cold and thermal) in the South Nahanni area of Northwest Territories, Canada. This area includes major scheelite skarn tungsten deposits (for example, the Cantung deposit). Some samples were located near tungsten occurrences. Anomalous areas were defined by the authors as $>15 \mu / 1$ tungsten. Primary tungsten minerals (scheelite and wolframite) are resistant to chemical weathering, however, tungsten as $\mathrm{WO}_{4}{ }^{-2}$ can be quite mobile in increasing alkaline conditions (Hall and others, 1988). Geothermal springs in the Fort Hamlin Hills area contain up to $200 \mu / 1$ tungsten (table 5, five of nine samples tested contain more than $200 \mu / 1$ ).

High calcium content in Ray River coal ash (appendix B, all samples exceeded detection level of 10 percent $\mathrm{Ca}$ ) suggests a calcic alkaline groundwater paleo-environment preceding or during the coal forming process.

Table 5. Analyses ${ }^{1}$ of geothermal water samples (in $\mu \mathrm{g} / 1$ ).

\begin{tabular}{|c|c|c|c|c|c|}
\hline $\begin{array}{l}\text { Map } \\
\text { Location } \\
\text { Number }\end{array}$ & $\begin{array}{l}\text { Sample } \\
\text { Number }\end{array}$ & Description & $\mathrm{W}$ & $\mathrm{Pb}$ & $\mathrm{U}$ \\
\hline A & 26360 & $\begin{array}{l}\text { Estimated total flow is } 650 \mathrm{l} / \mathrm{min} \text {; maximum temperature } \\
44.2^{\circ} \mathrm{C} ; \mathrm{pH}=8.7 \text {; at least } 4 \text { seeps. }\end{array}$ & $\mathrm{L}$ & $\mathrm{L}$ & $\mathrm{L}$ \\
\hline B-1 & 26362 & $\begin{array}{l}\text { Estimated total flow is unknown but as large or larger } \\
\text { than at sample A, numerous seeps along gravel bar for } \\
\text { about } 400 \mathrm{ft} \text { approximately along a trend of } 310^{\circ} \text {; } \\
\text { maximum temperature } 63^{\circ} \mathrm{C} ; \mathrm{pH} 8.6 \text { at sample site. }\end{array}$ & 200 & $\mathrm{~L}$ & $\mathrm{~L}$ \\
\hline $\mathrm{B}-2$ & 26001 & See B-1 above, temperature $62^{\circ} \mathrm{C}$ at sample site; $\mathrm{pH} 8.7$. & 200 & 16 & 0.08 \\
\hline B-3 & 26003 & $\begin{array}{l}\text { See B-1 above, temperature } 22^{\circ} \mathrm{C} \text { at sample site; } \mathrm{pH} 8.0 \text {. } \\
\text { This seep is a warm pool of red-brown colored water } \\
\text { that is favored by wildlife. }\end{array}$ & 200 & 16 & 10.03 \\
\hline $\mathrm{C}$ & 25735 & $\begin{array}{l}\text { Minor seeps on left limit river bank, estimated flow } 5-10 \\
1 / \text { min from several seeps along } 100 \mathrm{ft} \text {; maximum } \\
\text { temperature } 18^{\circ} \mathrm{C} ; \mathrm{pH} 7.6 \text {. }\end{array}$ & 40 & $\mathrm{~L}$ & $\mathrm{~L}$ \\
\hline $\mathrm{D}$ & 25734 & $\begin{array}{l}\text { Iron-stained seep below left-limit gravel bank, very } \\
\text { minor flow mixed with snowmelt; maximum } \\
\text { temperature } 5^{\circ} \mathrm{C}, \mathrm{pH} 5.8 \text {. }\end{array}$ & $\mathrm{L}$ & $\mathrm{L}$ & 0.46 \\
\hline $\mathrm{E}$ & & $\begin{array}{l}\text { Very minor seep with no flow; maximum temperature } \\
12^{\circ} \mathrm{C} \text {, no sample possible. }\end{array}$ & $\mathrm{N}$ & $\mathrm{N}$ & $\mathrm{N}$ \\
\hline F-1 & 26361 & $\begin{array}{l}\text { Swampy area } 500 \mathrm{ft} \text { by } 300 \mathrm{ft} \text { with } 14 \text { separate springs; } \\
\text { total flow estimated at } 430 \mathrm{l} / \mathrm{min} \text {; maximum temperature } \\
55^{\circ} \mathrm{C} \text { (this sample), } \mathrm{pH} 8.6 \text {. }\end{array}$ & 200 & $\mathrm{~L}$ & 1.0 \\
\hline F-2 & 26364 & $\begin{array}{l}\text { See } \mathrm{F}-1 \text { above, this sample site temperature } 54.8^{\circ} \mathrm{C}, \mathrm{pH} \\
8 \text {. }\end{array}$ & 200 & $\mathrm{~L}$ & $\mathrm{~L}$ \\
\hline $\begin{array}{l}\text { Detection } \\
\text { Limit }\end{array}$ & & & 20 & 4 & 0.05 \\
\hline
\end{tabular}

${ }^{1}$ analyses by Chemex Labs, Inc., Sparks, NV, using inductively coupled plasma - atomic emission spectrography except $U$ by fluorimetric procedure.

$\mathrm{L}=$ less than detection limit

$\mathrm{N}=$ no analysis 


\section{MICROPROBE AND SEM STUDIES}

Microprobe and scanning electron microscope (SEM) examinations of coal grain-mounts were undertaken to determine if specific elements are concentrated in minerals along secondary fractures and voids, or are uniformly distributed throughout the coal, suggesting mineralized waters circulated through plant material or peat bogs prior to diagenesis. X-ray image scans ${ }^{4}$ of samples with map numbers 5, 6, and 9 (fig. 5) show germanium randomly distributed throughout specimens 5 and 6 and unrelated to bedding, fractures, or voids. Similarly, widely dispersed concentrations of tungsten were found in sample map numbers 6 and 9, but again they did not correlate to postdiagenetic fluid pathways. SEM examination of map number 5 using backscattered electron detection showed numerous bright specks identified as lead-containing particles (fig. 7). X-ray image scans ${ }^{5}$ of coal from map numbers 10 and 14 (fig. 5) for gold, silver, copper, zinc, uranium, thorium, and rare earth elements found these elements widely dispersed and did not find any areas of concentration in any of the specimens. Conversely, X-ray scans for lead found numerous unidentified lead-containing particles, some of which occur on fracture surfaces. Figures $7 \mathrm{e}, 8$, and 9 show typical lead particles in fractures, indicating secondary lead mineralization. The accompanying X-ray image scans for sulfur, calcium, and tungsten (fig. 7) demonstrate these elements are disseminated within the coal structure. Figure 8 shows the concentration of elemental lead peripheral to a larger grain containing $\mathrm{Fe}$ and $\mathrm{S}$ (probably pyrite); however, no localized concentrations of tungsten or germanium were found.

\footnotetext{
${ }^{4}$ Analyses by J. Watson, Analyst, Albany Research Center, U.S. Bureau of Mines, Albany, OR 97321

${ }^{5}$ Lee Eminhizer, Analyst, Pennsylvania State University, University Park, PA 16802
} 


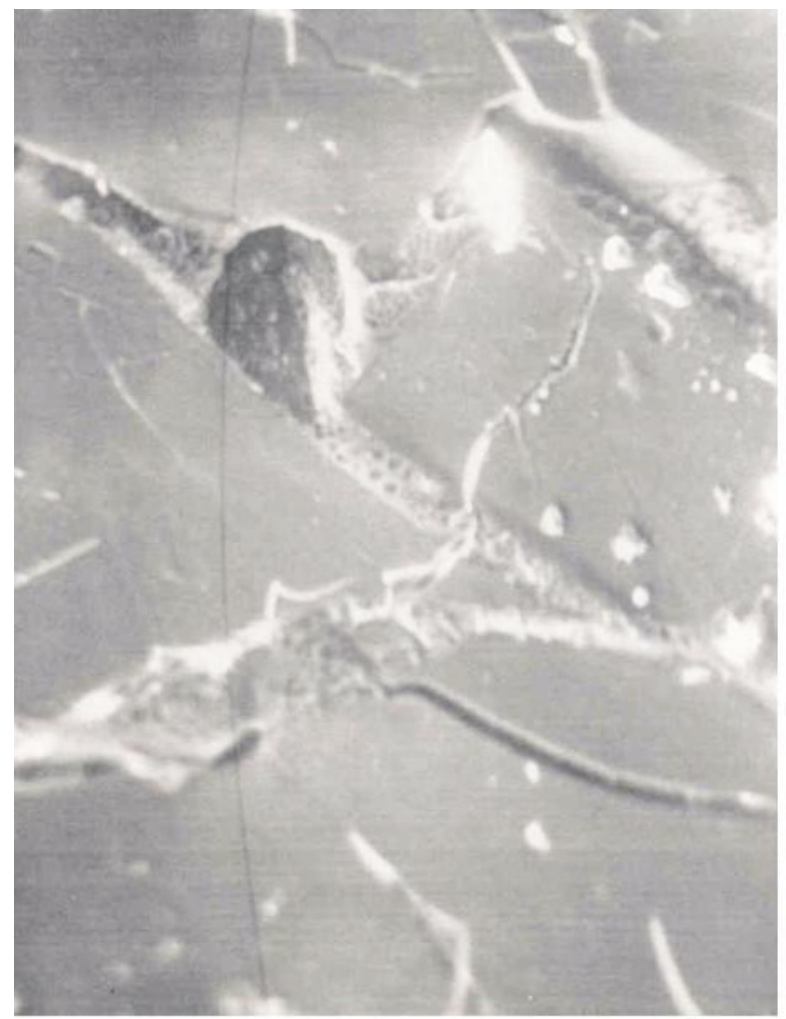

(a) Scanning Electron Microscope (SEM) photo of coal sample Rm25445, map no. 5

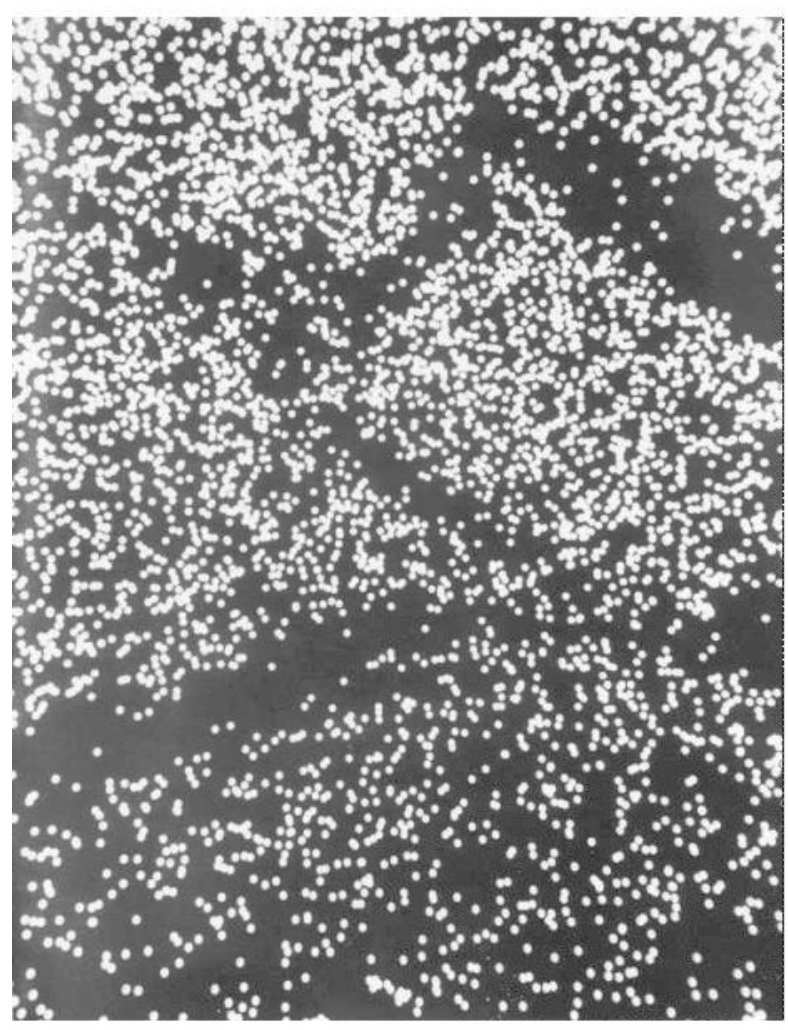

(c) X-ray plot of sulfur (S)

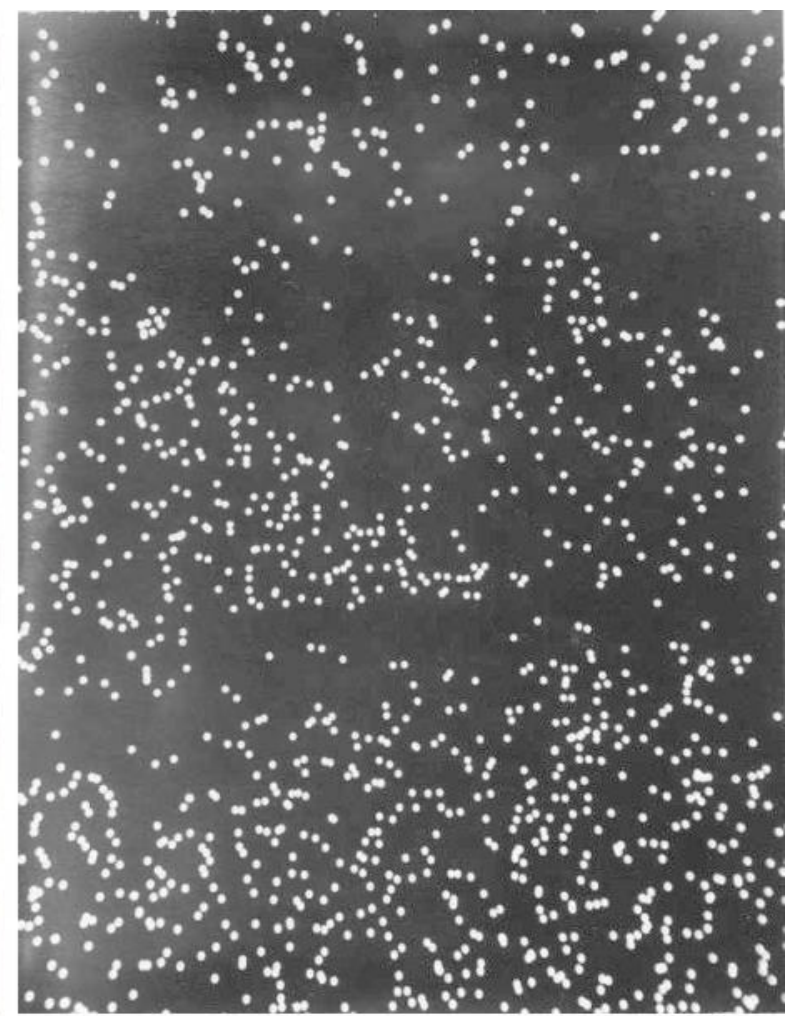

(b) X-ray plot of calcium (Ca)

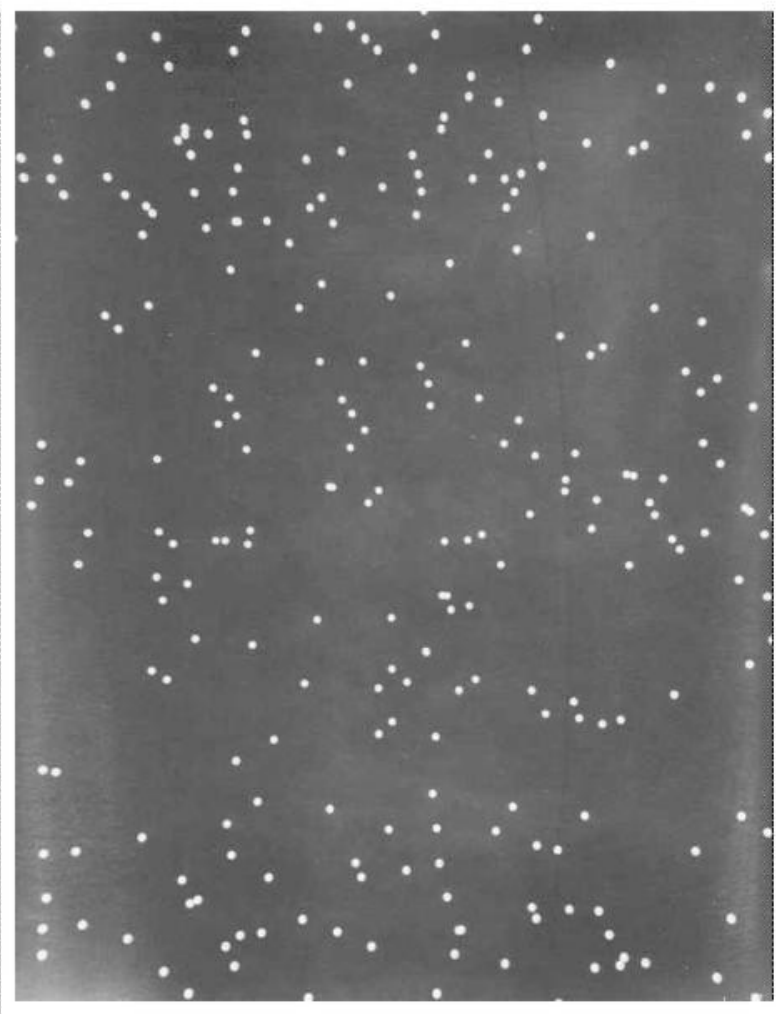

(d) X-ray plot of tungsten (W) 


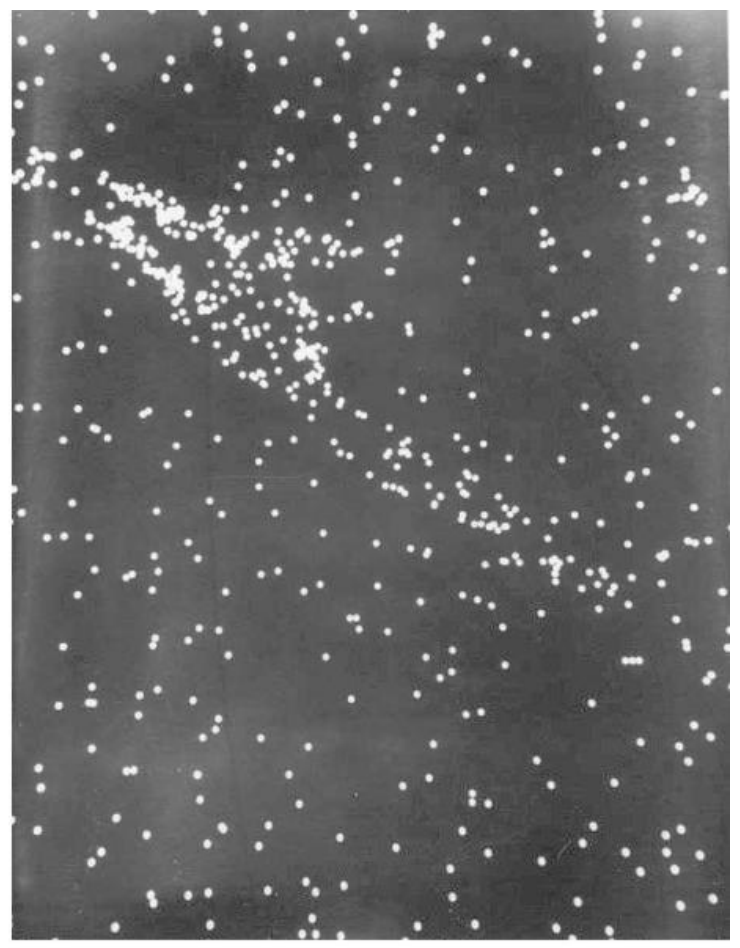

(e) X-ray plot of lead $(\mathrm{Pb})$

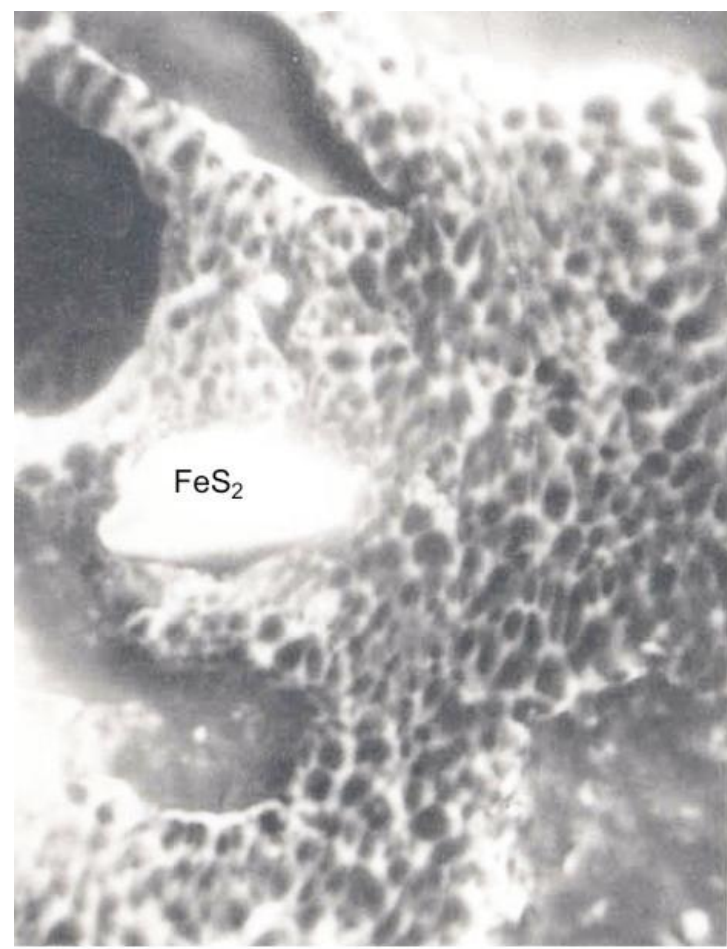

(a) Scanning Electron Microscope (SEM) photo of coal sample Rm25448, map no. 10.
Figure 7a-e. Photomicrograph of coal sample no. 5 and $X$-ray plots of $C a, S, W$, and $P b$.

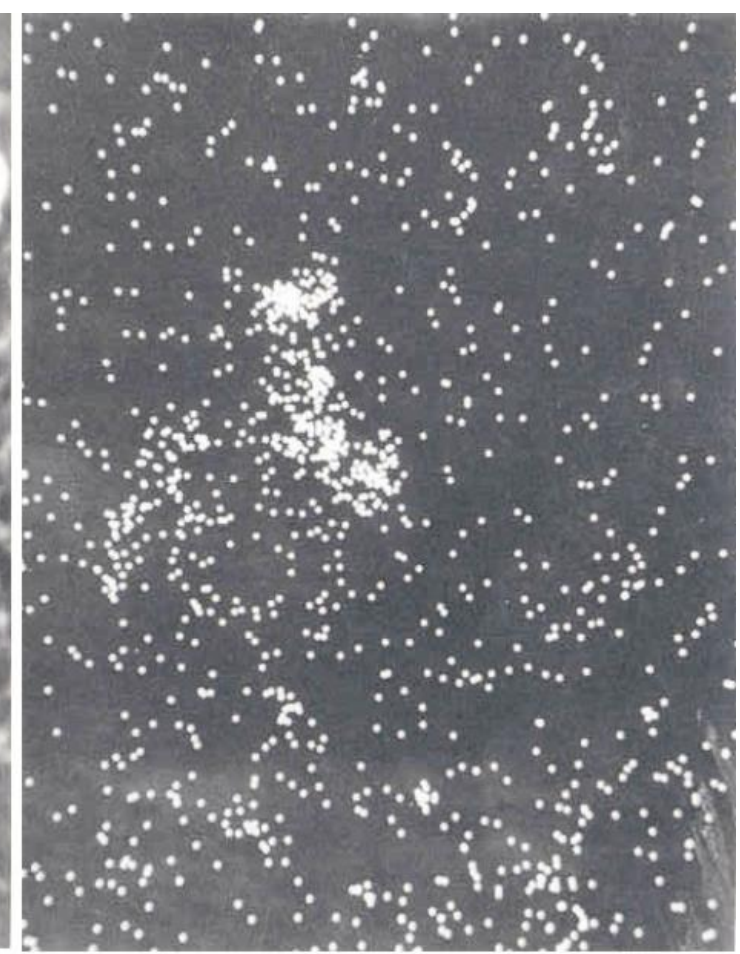

(b) X-ray plot of lead $(\mathrm{Pb})$

Figure 8a-b. Photomicrograph of coal sample no. 10, showing a grain of pyrite $\left(\mathrm{FeS}_{2}\right)$ and $\mathrm{X}$-ray plot of $\mathrm{Pb}$. 


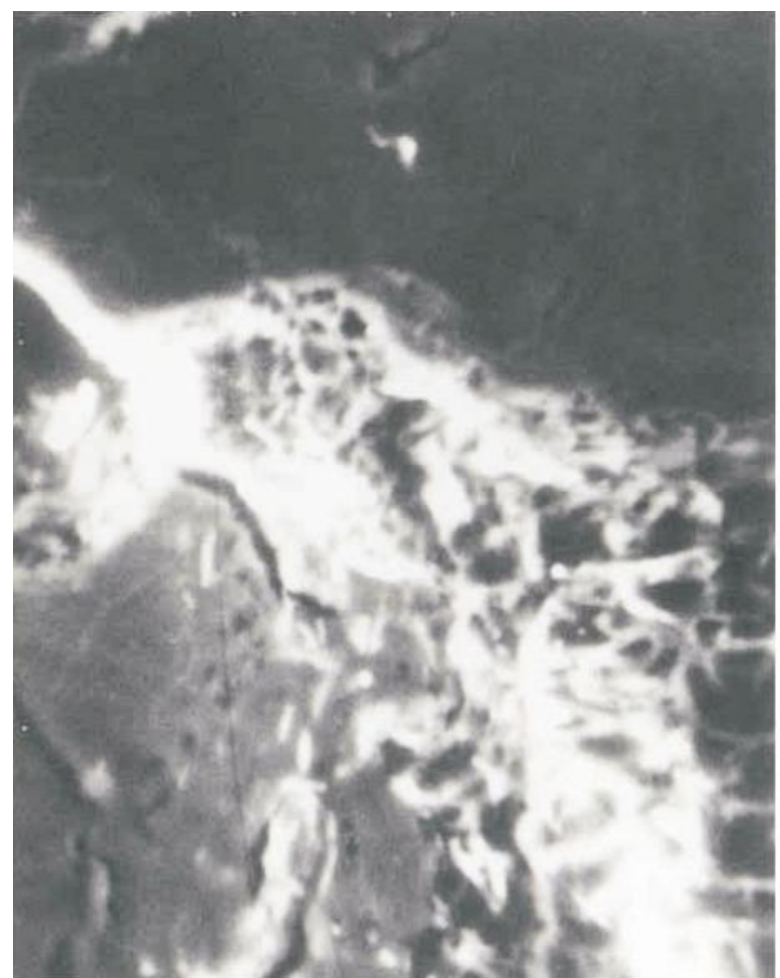

(a) Scanning Electron Microscope (SEM) photo of coal sample Rm25450, map no. 14 .

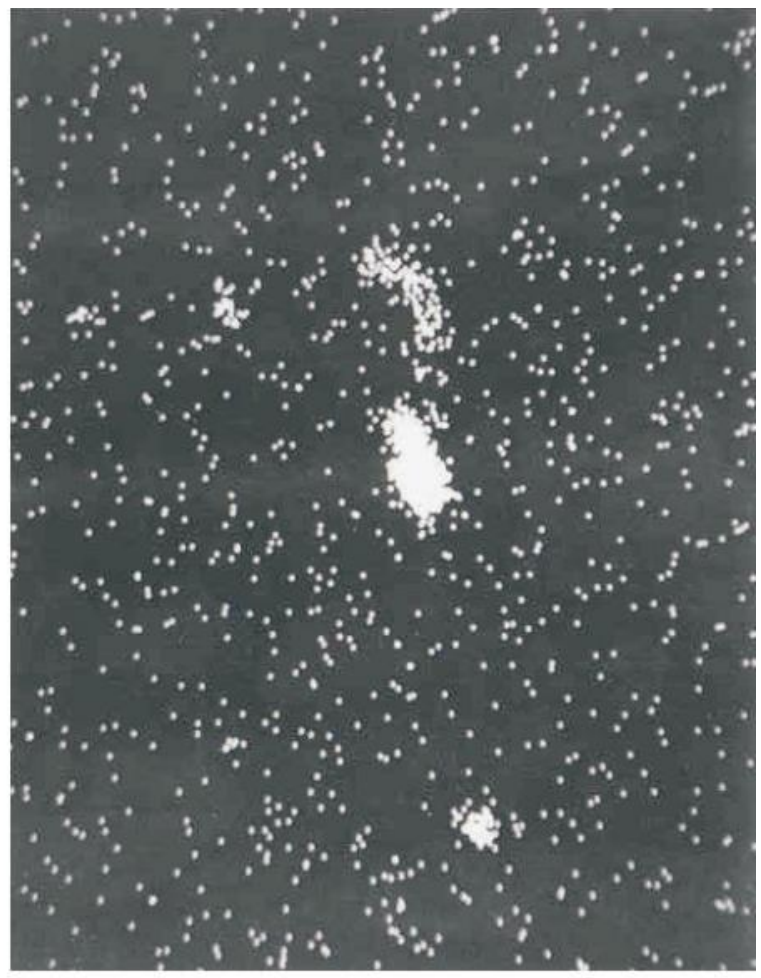

(b) X-ray plot of lead $(\mathrm{Pb})$

Figure 9a-b. Photomicrograph of coal sample no. 14, showing crystal-like particles of $\mathrm{Pb}$ in fracture zone and $X$-ray plot of $\mathrm{Pb}$.

\section{DISCUSSION AND CONCLUSIONS}

Although the Fort Hamlin Hills area is extensively covered with recent surficial deposits and vegetation, mapping and analytical data indicate an extensional terrane in which obscure graben-like basins have preserved coal-bearing sedimentary rocks. The occurrence of layered alkaline fissure basalts, the geochemistry of the Tertiary sediments, geothermal activity with associated anomalous mobile metal ion content, and the stepped elevations of the Tertiary-age coal beds are consistent with an interpreted formation of at least limited rifting and graben formation between several Cretaceous granitic plutons. Tertiary basalt flows, approximately $200 \mathrm{ft}(61 \mathrm{~m})$ thick or more and covering about 60 square mi $(155$ square $\mathrm{km})$ have been downcut by the present stream pattern, indicative of further subsidence relative to the highlands.

Trace metal values, particularly tungsten, are highly concentrated in coal beds underlying the Ray River. Nearby coal beds in the Dall River valley are not similarly mineralized, however, the overlying lacustrine mudstone and water-lain tuff unit is enriched in tungsten. Because geothermal springs and seeps in the area presently contain anomalous levels of mobile tungsten, it is likely that calcic paleo-geothermal activity, possibly more active in the past than now, either concentrated metals including tungsten in plant material at the time, or circulated in former peat bogs beneath the capping basalt flows. An inverse relationship between percent ash and ppm tungsten in Ray River coal ash samples indicates the tungsten in coal is associated with the organic macerals rather than terrestrial mineral matter. Coal diluted with abundant ash contains correspondingly less metal-bearing maceral material.

It is unclear why the Dall River coal beds are not similarly mineralized, however, the timing of mineralized geothermal waters in the area and the overlying mudstone/ash accumulations may be responsible.

Data suggest that a lake fed by geothermal waters, possibly with some similarities to Searles Lake, California (Ririe, 1989; Carpenter and Garrett, 1959), formed in the Dall River-Coal Creek area, thus accounting for the water- 
lain nature of the mineralized mudstones and tuff. Present-day mud and brine at Searles Lake contain up to 118 ppm $\mathrm{WO}_{3}$. The Dall River carbonaceous lacustrine mudstones are enriched in tungsten (up to $190 \mathrm{ppm}$ ), uranium (up to $50 \mathrm{ppm}$ ), and other trace metals; veinlets of a hydrate apatite were identified, as well as vivianite and zeolite beds. Further study of deposition, geochemistry, and paleo-climate is suggested.

In the Ray River watershed the coal section was covered by basalt flows. The basalt flows provided the opportunity for a closed aquifer in which underlying metal-bearing geothermal springs could saturate the coalforming beds. Microprobe study of Ray River coal specimens indicates metals (except lead) are diffused throughout the coal at molecular levels and do not show post-diagenesis concentration along bedding or fracture surfaces. Lead, conversely, at least partially concentrates along fractures, indicating a phase of secondary mineralization. Up to 1.9 percent tungsten, 1.9 percent lead, and 1.2 percent germanium are found in ash prepared from Ray River coal.

Significant concentrations of tungsten in coal have been noted in at least two other sites in the world. Both feature geologic settings similar to the Fort Hamlin Hills area. At Death Valley on Alaska's Seward Peninsula, a coal-bearing Eocene section is exposed in a graben partially overlain by basalt flows (Dickinson and others, 1987). Sandstone is mineralized with secondary uranium, and lignite contains up to $360 \mathrm{ppm}$ tungsten on a whole coal basis (Stricker and Affolter, 1988). Drainage into and under the Death Valley basalt emanates from the Darby Mountains granitic pluton where vein-type uranium mineralization occurs (Foley and Barker, 1986).

The second site is in southern Bulgaria, at the Pirin and Mugla coal fields (Eskenazy, 1982). Tungsten concentrations up to $4,335 \mathrm{ppm}$ are measured in coal ash, with the highest values found near the base of the coal beds. Eskenazy (written communication), suggests that the tungsten mineralization is associated with nitrogenbearing thermal waters containing detectable tungsten that flow from geothermal springs in the vicinity of tungstenmineralized granitoids. A similar geothermal correlation to tungsten is discussed by Ririe (1989).

The occurrence of germanium in coal ash is somewhat more common worldwide, although rarely at the concentration levels found in coal ash from the Fort Hamlin Hills area. An example is located north of Vancouver, where lignite and carbonaceous sandstone, termed "brown beds," contain 50 to $60 \mathrm{ppm}$ germanium (Queneau and others, 1988). It was noted that germanium was highly concentrated in vitrinite ( 0.2 to 0.5 percent), and the vitrinite could be concentrated by flotation techniques.

Because nearly all samples collected from the Ray River basin contain highly anomalous levels of tungsten and other metals, it is likely that a substantial resource is present from which coal and rare metals may be extracted. Drilling of this resource is necessary for further quantification. Although none of the samples from the nearby Dall River basin contained metal values high enough to be of economic interest, further exploration there is warranted.

\section{REFERENCES}

Albanese, M.D., 1987, A basalt flow in the Fort Hamlin Hills, Bettles A-1 Quadrangle: Alaska Division of Geological \& Geophysical Surveys Public-data File 87-25, 8 p.

American Society for Testing Materials (ASTM), 1979, Standard specification for classification of coals by rank, in Annual Book of ASTM Standards; Part 26: Philadelphia, PA, ASTM International, p. 220-223.

Arth J.G., Zmuda, C.C., Foley, N.K., Criss, R.E., Patton, W.W., and Miller, T.P., 1989, Isotopic and trace element variations in the Ruby batholith, Alaska, and the nature of the deep crust beneath the Ruby and Angayucham Terranes: Journal of Geophysical Research, v. 94, no. B11, p. 15,941-15,955.

Barker, J.C., 1981, Coal and uranium investigation of the Yukon Flats Cenozoic basin: Bureau of Mines Open File Report 140-81, $63 \mathrm{p}$.

Barker, J.C., 1991, Tin placers associated with the downcutting of fissure basalts, Ray River Drainage, Alaska, in Reger, R.D., ed., Short Notes on Alaskan Geology 1991: Alaska Division of Geological \& Geophysical Surveys Professional Report 111, p. 1-8.

Barker, J.C., and Goff, K.M., 1986, Coal resources within the Yukon River drainage, Interior Alaska. Symposium proceedings - Focus on Alaska Coal, 1986: Mineral Industry Research Lab, University of Alaska, Report 72, p. 336-349.

Carpenter, L.G., and Garrett, D.E., 1959, Tungsten in Searles Lake: Mining Engineering, v. 11, no. 3, p. 301-303.

Clautice, K.H., and Mowatt, T.C., 1981, Trona occurrences within the Yukon Flats Basin, Alaska: U.S. Bureau of Mines Open-file Report 69-81, 34 p.

Dickinson, K.A., Cunningham, K.D., and Ager, T.A., 1987, Geology and origin of the Death Valley uranium deposit, Seward Peninsula, Alaska: Economic Geology, v. 82, p. 1558-1574.

Eskenazy, G.M., 1982, The geochemistry of tungsten in Bulgarian coals: International Journal of Coal Geology, v. 2, no. 2, p. 99-111.

Foley, J.Y., and Barker, J.C., 1986, Uranium occurrences in the northern Darby Mountains, Seward Peninsula, Alaska: U.S. Bureau of Mines Information Circular 9103, 27 p. 
Hall, G.E.M., Jefferson, C.W., and Michel, F.A., 1988, Determination of W and Mo in natural spring waters by ICPAES and ICP-MS; Application to South Nahanni River Area, N.W.T., Canada: Journal of Geochemical Exploration, v. 30, no. 1, p. 63-84.

Merritt, R.D., and Hawley, C.C., 1986, Map of Alaska's coal resources: Alaska Division of Geological \& Geophysical Surveys Special Report 37, 1 sheet.

Queneau, P.B., Avotins, P.V., and Farris, L.F., 1988, Germanium recovery from Fargo Oil's Lang Bay property: Canadian Institute of Mining, v. 79, no. 886, p. 92-97.

Rao, P.D., 1968, Distribution of certain minor elements in Alaskan coals: Mineral Industry Research Lab, University of Alaska, Report 15, 45 p.

Ririe, G.T., 1989, Evaporates and strata-bound tungsten mineralization: Geology, v. 17, no. 2, p. 139-143.

Stricker, G.D., and Affolter, R.H., 1988, Eocene lava and epigene mineralization alter Alaska's thickest known coal deposit, in Carter, L.M., ed., USGS research on energy resources, 1988; program and abstracts: U.S. Geological Survey Circular 1025, p. 59-60.

Valkovic, Vlado, 1983, Trace elements in coal, v. I and II: Boca Raton, Florida, CRC Press, 491 p.

Williams, J.R., 1962, Geologic reconnaissance of the Yukon Flats district, Alaska: U.S. Geological Survey Bulletin 1111-H, p. 289-331. 
Appendix A-1. Multi-element analyses by neutron activation of coal ash ${ }^{1}$, Ray River coal samples.

\begin{tabular}{|c|c|c|c|c|c|c|c|c|c|c|c|c|c|c|c|c|c|c|c|}
\hline $\begin{array}{l}\text { Sample / } \\
\text { Map } \\
\text { Location } \\
\text { Nos. }\end{array}$ & $\begin{array}{l}\mathrm{Au}, \\
\mathrm{ppb}\end{array}$ & $\begin{array}{l}\mathrm{Sb}, \\
\mathrm{ppm}\end{array}$ & $\begin{array}{l}\text { As, } \\
\text { ppm }\end{array}$ & $\begin{array}{l}\mathrm{Ba}, \\
\mathrm{ppm}\end{array}$ & $\begin{array}{l}\mathrm{Br} \\
\mathrm{ppm}\end{array}$ & $\begin{array}{l}\mathrm{Cd}, \\
\mathrm{ppm}\end{array}$ & $\begin{array}{l}\text { Ce, } \\
\text { ppm }\end{array}$ & $\begin{array}{l}\text { Cs, } \\
\text { ppm }\end{array}$ & $\begin{array}{l}\text { Cr, } \\
\text { ppm }\end{array}$ & $\begin{array}{l}\text { Co, } \\
\text { ppm }\end{array}$ & $\begin{array}{l}\mathrm{Eu}, \\
\mathrm{ppm}\end{array}$ & $\begin{array}{l}\text { Hf, } \\
\text { ppm }\end{array}$ & $\begin{array}{l}\mathrm{Ir}, \\
\mathrm{ppb}\end{array}$ & $\begin{array}{l}\text { Fe, } \\
\text { pct }\end{array}$ & $\begin{array}{l}\mathrm{La}, \\
\mathrm{ppm}\end{array}$ & $\begin{array}{l}\mathrm{Lu}, \\
\mathrm{ppm}\end{array}$ & $\begin{array}{l}\text { Mo, } \\
\text { ppm }\end{array}$ & $\begin{array}{l}\mathrm{Ni}, \\
\mathrm{ppm}\end{array}$ & $\begin{array}{l}\mathrm{Rb}, \\
\mathrm{ppm}\end{array}$ \\
\hline RM25445/5 & 38 & 170.0 & 1030.0 & 2200 & 2.8 & $<19$ & 641.0 & 22.0 & 300 & 47 & $<3$ & $<5$ & $<120$ & 8.5 & 226 & 20.0 & 119 & 110 & 64 \\
\hline RM25446/6 & 21 & 179.0 & 551.0 & 1100 & $<2.0$ & $<18$ & 579.0 & 14.0 & 190 & 140 & 8 & 6 & $<110$ & 13.0 & 209 & 15.0 & 215 & 1470 & 41 \\
\hline RM25447/9 & 79 & 296.0 & 418.0 & 1500 & $<2.0$ & $<23$ & 340.0 & 2.0 & 210 & 26 & $<4$ & $<6$ & $<140$ & 10.0 & 100 & 20.0 & 96 & 390 & 18 \\
\hline RM25448/10 & 61 & 3330.0 & 2590.0 & $<620$ & 110.0 & $<61$ & 570.0 & 7.4 & $<310$ & 40 & $<15$ & $<12$ & $<370$ & 8.2 & 220 & 29.9 & 91 & $<85$ & 91 \\
\hline RM25449/12 & $<14$ & 486.0 & 286.0 & 410 & 15.0 & $<16$ & 686.0 & 34.0 & 71 & 19 & 5 & 7 & $<50$ & 2.0 & 295 & 10.0 & 43 & $<24$ & 130 \\
\hline RM25450/14 & 204 & 2710.0 & 1690.0 & 1200 & 82.0 & $<47$ & 160.0 & $<2.7$ & $<240$ & 58 & 12 & $<9$ & $<280$ & 6.5 & 58 & 8.5 & 76 & 140 & $<46$ \\
\hline RM24723/16 & 222 & 339.0 & 980.0 & 520 & 29.0 & $<29$ & 100.0 & $<0.5$ & 550 & 41 & 2 & $<5$ & $<100$ & 3.3 & 37 & 4.8 & 330 & 120 & $<14$ \\
\hline RM24725/20 & $<17$ & 59.3 & 527.0 & $<1200$ & 6.1 & $<24$ & 200.0 & 23.0 & 91 & 26 & 3 & 9 & $<50$ & 5.7 & 86 & 7.0 & 130 & 130 & 69 \\
\hline RM24726/19 & 1870 & 234.0 & 874.0 & $<670$ & 15.0 & $<30$ & 820.0 & 26.0 & 250 & 88 & 4 & $<4$ & $<100$ & 6.9 & 280 & 6.0 & 185 & 200 & 74 \\
\hline RM24727/18 & 56 & 118.0 & 897.0 & $<1500$ & 14.0 & $<35$ & 230.0 & 3.4 & $<100$ & 210 & $<1$ & $<5$ & $<120$ & 9.4 & 84 & 14.0 & 630 & 320 & $<19$ \\
\hline (continued) & $\begin{array}{l}\mathrm{Sm}, \\
\mathrm{ppm}\end{array}$ & $\begin{array}{c}\mathrm{Sc}, \\
\mathrm{ppm}\end{array}$ & $\begin{array}{c}\mathrm{Se}, \\
\mathrm{ppm}\end{array}$ & $\begin{array}{l}\mathrm{Ag}, \\
\mathrm{ppm}\end{array}$ & $\begin{array}{l}\mathrm{Na}, \\
\text { pct }\end{array}$ & $\begin{array}{c}\mathrm{Ta}, \\
\mathrm{ppm}\end{array}$ & $\begin{array}{c}\mathrm{Te}, \\
\mathrm{ppm}\end{array}$ & $\begin{array}{c}\mathrm{Tb}, \\
\mathrm{ppm}\end{array}$ & $\begin{array}{c}\text { Th, } \\
\text { ppm }\end{array}$ & $\begin{array}{c}\text { Sn, } \\
\text { ppm }\end{array}$ & $\begin{array}{c}\mathrm{W}, \\
\mathrm{ppm}\end{array}$ & $\begin{array}{c}\mathrm{U}, \\
\mathrm{ppm}\end{array}$ & $\begin{array}{c}\mathrm{Yb}, \\
\mathrm{ppm}\end{array}$ & $\begin{array}{c}\mathrm{Zn}, \\
\mathrm{ppm}\end{array}$ & $\begin{array}{c}\mathrm{Zr}, \\
\mathrm{ppm}\end{array}$ & $\begin{array}{l}\mathrm{Cu}, \\
\mathrm{ppm}\end{array}$ & $\begin{array}{c}\mathrm{Sr}, \\
\mathrm{ppm}\end{array}$ & $\begin{array}{c}\mathrm{Y}, \\
\mathrm{ppm}\end{array}$ & \\
\hline RM25445/5 & 33.70 & 46.8 & $<13$ & $<6$ & 0.35 & 3.6 & $<160$ & 8.0 & 260.0 & $<380$ & 3790 & 322.0 & 38 & 160 & 1500 & 210 & -- & -- & \\
\hline RM25446/6 & 53.90 & 53.3 & $<12$ & $<6$ & 0.25 & 1.8 & $<80$ & 13.0 & 102.0 & $<350$ & 2730 & 171.0 & 61 & 170 & 1600 & 95 & -- & -- & \\
\hline RM25447/9 & 26.80 & 43.5 & $<16$ & $<6$ & $<0.20$ & 2.2 & $<130$ & 9.2 & 192.0 & $<470$ & 5190 & 311.0 & 50 & 180 & 1900 & 79 & -- & -- & \\
\hline RM25448/10 & 49.20 & 37.3 & $<45$ & 86 & $<1.60$ & $<2.1$ & $<230$ & 8.0 & 226.0 & $<1500$ & 1660 & 299.0 & 130 & $<320$ & $<2400$ & 132 & -- & -- & \\
\hline RM25449/12 & 62.80 & 31.3 & $<11$ & $<5$ & 0.67 & 3.7 & $<57$ & 10.0 & 149.0 & $<370$ & 424 & 147.0 & 38 & 140 & 1700 & 40 & -- & -- & \\
\hline RM25450/14 & 18.00 & 42.5 & $<34$ & 37 & $<1.50$ & $<1.6$ & $<180$ & 3.1 & 51.6 & $<1200$ & 308 & 44.0 & 77 & 390 & $<1700$ & 129 & -- & -- & \\
\hline RM24723/16 & 14.90 & 36.3 & $<13$ & $<2$ & 0.20 & 4.1 & $<47$ & 6.6 & 95.1 & $<400$ & $>2000$ & 101.0 & 29 & $<200$ & 1500 & 1021 & 812 & 278 & \\
\hline RM24725/20 & 20.70 & 75.9 & $<11$ & $<5$ & 0.19 & 5.0 & $<51$ & 9.1 & 234.0 & $<350$ & $>2000$ & 342.0 & 56 & $<100$ & $<980$ & 153 & 464 & 468 & \\
\hline RM24726/19 & 67.60 & 53.7 & $<14$ & $<6$ & 0.22 & 2.2 & $<50$ & 14.0 & 124.0 & $<420$ & $>2000$ & 183.0 & 40 & 490 & $<790$ & 3709 & 380 & 405 & \\
\hline RM24727/18 & 20.50 & 68.6 & $<15$ & $<5$ & 0.16 & 3.4 & $<71$ & 13.0 & 213.0 & $<420$ & $>2000$ & 411.0 & 96 & $<100$ & $<1200$ & 199 & 531 & 856 & \\
\hline
\end{tabular}

1 Analyses by Bondar-Clegg Co. Ltd., Vancouver, B.C., using instrumented neutron activation; exceptions: copper by atomic absorption and strontium and yttrium by inductively coupled plasma.

$--=$ not analyzed 
Appendix A-2. Multi-element analyses by neutron activation of coal $\mathrm{ash}^{1}$, Dall River coal samples.

\begin{tabular}{|c|c|c|c|c|c|c|c|c|c|c|c|c|c|c|c|c|c|c|c|}
\hline $\begin{array}{l}\text { Sample / } \\
\text { Map } \\
\text { Location } \\
\text { Nos. }\end{array}$ & $\begin{array}{l}\mathrm{Au}, \\
\mathrm{ppb}\end{array}$ & $\begin{array}{l}\mathrm{Sb}, \\
\mathrm{ppm}\end{array}$ & $\begin{array}{l}\text { As, } \\
\text { ppm }\end{array}$ & $\begin{array}{l}\mathrm{Ba}, \\
\mathrm{ppm}\end{array}$ & $\begin{array}{l}\mathrm{Br} \\
\mathrm{ppm}\end{array}$ & $\begin{array}{l}\mathrm{Cd}, \\
\mathrm{ppm}\end{array}$ & $\begin{array}{l}\mathrm{Ce}, \\
\mathrm{ppm}\end{array}$ & $\begin{array}{l}\text { Cs, } \\
\text { ppm }\end{array}$ & $\begin{array}{l}\mathrm{Cr}, \\
\mathrm{ppm}\end{array}$ & $\begin{array}{l}\text { Co, } \\
\text { ppm }\end{array}$ & $\begin{array}{l}\mathrm{Eu}, \\
\mathrm{ppm}\end{array}$ & $\begin{array}{l}\text { Hf, } \\
\text { ppm }\end{array}$ & $\begin{array}{l}\mathrm{Ir} \\
\mathrm{ppb}\end{array}$ & $\begin{array}{l}\text { Fe, } \\
\text { pct }\end{array}$ & $\begin{array}{l}\mathrm{La}, \\
\mathrm{ppm}\end{array}$ & $\begin{array}{l}\mathrm{Lu}, \\
\mathrm{ppm}\end{array}$ & $\begin{array}{l}\text { Mo, } \\
\text { ppm }\end{array}$ & $\begin{array}{l}\mathrm{Ni} \text {, } \\
\text { ppm }\end{array}$ & $\begin{array}{c}\mathrm{Rb}, \\
\mathrm{ppm}\end{array}$ \\
\hline HZ25636/22 & $<8$ & 68.6 & 207.0 & 5800 & 3.7 & $<5$ & 300.0 & 0.8 & 66 & 28 & 6 & 7 & $<50$ & 9.4 & 190 & 3.4 & 22 & 570 & $<12$ \\
\hline HZ25638/23 & 27 & 95.0 & 361.0 & 4600 & 6.7 & $<5$ & 270.0 & 3.1 & 65 & 39 & 3 & 4 & $<50$ & 9.0 & 120 & 5.0 & 10 & 310 & 16 \\
\hline HZ25639/24 & $<7$ & 77.6 & 215.0 & 3700 & 3.2 & $<5$ & 250.0 & $<0.5$ & 52 & 140 & 3 & $<1$ & $<50$ & 13.0 & 130 & 3.0 & 17 & 790 & $<13$ \\
\hline HZ25641/25 & 23 & 58.4 & 178.0 & 10700 & 3.6 & $<11$ & 250.0 & $<0.5$ & $<52$ & 28 & 4 & 10 & $<50$ & 7.2 & 120 & 2.0 & 55 & 360 & $<14$ \\
\hline HZ25642/26 & 5 & 39.8 & 204.0 & 490 & 2.6 & $<5$ & 55.0 & 8.7 & 200 & 8 & $<1$ & 7 & $<50$ & 2.5 & 37 & 0.8 & 6 & $<20$ & 36 \\
\hline (continued) & $\begin{array}{l}\mathrm{Sm}, \\
\mathrm{ppm}\end{array}$ & $\begin{array}{c}\mathrm{Sc}, \\
\mathrm{ppm}\end{array}$ & $\begin{array}{c}\mathrm{Se}, \\
\mathrm{ppm}\end{array}$ & $\begin{array}{l}\mathrm{Ag}, \\
\mathrm{ppm}\end{array}$ & $\begin{array}{l}\mathrm{Na}, \\
\text { pct }\end{array}$ & $\begin{array}{c}\mathrm{Ta}, \\
\mathrm{ppm}\end{array}$ & $\begin{array}{c}\text { Te, } \\
\text { ppm }\end{array}$ & $\begin{array}{c}\mathrm{Tb}, \\
\mathrm{ppm}\end{array}$ & $\begin{array}{l}\text { Th, } \\
\text { ppm }\end{array}$ & $\begin{array}{c}\text { Sn, } \\
\text { ppm }\end{array}$ & $\begin{array}{c}\mathrm{W}, \\
\mathrm{ppm}\end{array}$ & $\begin{array}{c}\mathrm{U}, \\
\mathrm{ppm}\end{array}$ & $\begin{array}{c}\mathrm{Yb}, \\
\mathrm{ppm}\end{array}$ & $\begin{array}{c}\mathrm{Zn}, \\
\mathrm{ppm}\end{array}$ & $\begin{array}{c}\mathrm{Zr}, \\
\mathrm{ppm}\end{array}$ & $\begin{array}{c}\mathrm{Cu}, \\
\mathrm{ppm}\end{array}$ & $\begin{array}{c}\mathrm{Sr}, \\
\mathrm{ppm}\end{array}$ & $\begin{array}{c}\mathrm{Y}, \\
\mathrm{ppm}\end{array}$ & \\
\hline HZ25636/22 & 37.40 & 24.9 & $<5$ & $<5$ & 0.21 & $<0.5$ & $<32$ & 5.8 & 10.0 & $<220$ & 205 & 29.5 & 18 & $<100$ & $<520$ & 82 & -- & -- & \\
\hline HZ25638/23 & 28.90 & 17.0 & $<5$ & $<4$ & 0.23 & $<0.5$ & 34 & 4.8 & 18.0 & $<230$ & 39 & 71.9 & 15 & 150 & 550 & 177 & -- & -- & \\
\hline HZ25639/24 & 28.00 & 17.0 & $<5$ & $<4$ & $<0.07$ & 0.5 & $<30$ & 4.3 & 5.9 & $<200$ & 23 & 30.2 & 14 & 210 & $<500$ & 74 & -- & -- & \\
\hline HZ25641/25 & 32.40 & 29.6 & $<5$ & $<5$ & 0.23 & 1.0 & $<34$ & 5.1 & 15.0 & $<230$ & 18 & 6.6 & 18 & 150 & $<580$ & 56 & -- & -- & \\
\hline HZ25642/26 & 4.90 & 31.8 & $<5$ & $<2$ & 0.22 & 1.5 & $<10$ & 0.7 & 16.0 & $<100$ & 210 & 7.7 & 4 & 100 & 410 & 28 & -- & -- & \\
\hline
\end{tabular}

${ }^{1}$ Analyses by Bondar-Clegg Co. Ltd., Vancouver, B.C., using instrumented neutron activation, except copper, which was analyzed by atomic absorption.

$--=$ not analyzed 
Appendix B. Multi-element analyses by ICP of coal ash, Fort Hamlin Hills region (presentation conformed to Appendix A).

\begin{tabular}{|c|c|c|c|c|c|c|c|c|c|c|c|c|c|c|c|c|c|c|c|}
\hline $\begin{array}{l}\text { Sample / } \\
\text { Map } \\
\text { Location } \\
\text { Nos. }\end{array}$ & $\begin{array}{l}\mathrm{Au} \\
\mathrm{ppb}\end{array}$ & $\begin{array}{l}\mathrm{Sb}, \\
\mathrm{ppm}\end{array}$ & $\begin{array}{l}\text { As, } \\
\text { ppm }\end{array}$ & $\begin{array}{l}\mathrm{Ba}, \\
\mathrm{ppm}\end{array}$ & $\begin{array}{c}\mathrm{Br}, \\
\mathrm{ppm}\end{array}$ & $\begin{array}{l}\mathrm{Cd}, \\
\mathrm{ppm}\end{array}$ & $\begin{array}{l}\mathrm{Ce}, \\
\mathrm{ppm}\end{array}$ & $\begin{array}{l}\text { Cs, } \\
\text { ppm }\end{array}$ & $\begin{array}{l}\mathrm{Cr}, \\
\mathrm{ppm}\end{array}$ & $\begin{array}{l}\text { Co, } \\
\text { ppm }\end{array}$ & $\begin{array}{l}\mathrm{Eu}, \\
\mathrm{ppm}\end{array}$ & $\begin{array}{l}\text { Hf, } \\
\text { ppm }\end{array}$ & $\begin{array}{c}\mathrm{Ir} \\
\mathrm{ppb}\end{array}$ & $\mathrm{Fe}, \mathrm{pct}$ & $\begin{array}{l}\mathrm{La}, \\
\mathrm{ppm}\end{array}$ & $\begin{array}{l}\mathrm{Lu}, \\
\mathrm{ppm}\end{array}$ & $\begin{array}{l}\text { Mo, } \\
\text { ppm }\end{array}$ & $\begin{array}{l}\mathrm{Ni}, \\
\mathrm{ppm}\end{array}$ & $\begin{array}{l}\mathrm{Rb}, \\
\mathrm{ppm}\end{array}$ \\
\hline RM24723/16 & -- & 258 & 904 & 460 & -- & $<1$ & -- & -- & 307 & 48 & -- & -- & -- & 4.58 & 37 & -- & 307 & 183 & -- \\
\hline RM24725/20 & -- & 40 & 472 & 346 & -- & $<1$ & -- & -- & 58 & 40 & -- & -- & -- & 7.58 & 98 & -- & 165 & 131 & -- \\
\hline RM24726/19 & -- & 205 & 876 & 300 & -- & 2 & -- & -- & 88 & 107 & -- & -- & -- & $>10.00$ & 265 & -- & 219 & 246 & -- \\
\hline RM24727/18 & -- & 82 & 987 & 271 & -- & $<1$ & -- & -- & 70 & 254 & -- & -- & -- & $>10.00$ & 106 & -- & 610 & 370 & -- \\
\hline & & & & & & & & & & & & & & & & & & & \\
\hline (continued) & $\begin{array}{l}\mathrm{Sm}, \\
\mathrm{ppm}\end{array}$ & $\begin{array}{c}\mathrm{Sc}, \\
\mathrm{ppm}\end{array}$ & $\begin{array}{c}\mathrm{Se}, \\
\mathrm{ppm}\end{array}$ & $\begin{array}{l}\mathrm{Ag}, \\
\mathrm{ppm}\end{array}$ & $\begin{array}{l}\mathrm{Na}, \\
\text { pct }\end{array}$ & $\begin{array}{c}\mathrm{Ta} \\
\mathrm{ppm}\end{array}$ & $\begin{array}{c}\mathrm{Te}, \\
\mathrm{ppm}\end{array}$ & $\begin{array}{c}\mathrm{Tb}, \\
\mathrm{ppm}\end{array}$ & $\begin{array}{c}\text { Th, } \\
\text { ppm }\end{array}$ & $\begin{array}{c}\mathrm{Sn}, \\
\mathrm{ppm}\end{array}$ & $\begin{array}{c}\mathrm{W}, \\
\mathrm{ppm}\end{array}$ & $\begin{array}{c}\mathrm{U}, \\
\mathrm{ppm}\end{array}$ & $\begin{array}{c}\mathrm{Yb}, \\
\mathrm{ppm}\end{array}$ & $\begin{array}{c}\mathrm{Zn}, \\
\mathrm{ppm}\end{array}$ & $\begin{array}{c}\mathrm{Zr}, \\
\mathrm{ppm}\end{array}$ & $\begin{array}{c}\mathrm{Cu}, \\
\mathrm{ppm}\end{array}$ & $\begin{array}{c}\mathrm{Sr}, \\
\mathrm{ppm}\end{array}$ & $\begin{array}{c}\mathrm{Y}, \\
\mathrm{ppm}\end{array}$ & \\
\hline RM24723/16 & -- & "-- & -- & 4.4 & 0.19 & $<1$ & 16 & -- & -- & $<20$ & $>2000$ & -- & -- & $<1$ & 1004 & 1021 & 812 & 278 & \\
\hline RM24725/20 & -- & -- & -- & 2.4 & 0.34 & 33 & 19 & -- & -- & $<20$ & 1905 & -- & -- & 151 & 573 & 153 & 464 & 468 & \\
\hline RM24726/19 & -- & -- & -- & 5.8 & 0.37 & $<1$ & 23 & -- & -- & 56 & $>2000$ & -- & -- & 1018 & 578 & 3709 & 380 & 405 & \\
\hline RM24727/18 & -- & -- & -- & 2.5 & 0.29 & 9 & 32 & -- & -- & $<20$ & $>2000$ & -- & -- & 185 & 578 & 199 & 531 & 856 & \\
\hline (continued) & $\begin{array}{c}\mathrm{Pb}, \\
\mathrm{ppm}\end{array}$ & $\begin{array}{c}\mathrm{Bi}, \\
\mathrm{ppm}\end{array}$ & $\begin{array}{l}\mathrm{Mn}, \\
\text { pct }\end{array}$ & $\begin{array}{c}\mathrm{V}, \\
\mathrm{ppm}\end{array}$ & $\begin{array}{c}\mathrm{Li}, \\
\mathrm{ppm}\end{array}$ & $\begin{array}{c}\mathrm{Ga}, \\
\mathrm{ppm}\end{array}$ & $\begin{array}{l}\mathrm{Ti}, \\
\text { pct }\end{array}$ & $\begin{array}{l}\mathrm{Al}, \\
\text { pct }\end{array}$ & $\begin{array}{c}\mathrm{Mg}, \\
\text { pct }\end{array}$ & $\begin{array}{l}\mathrm{Ca}, \\
\text { pct }\end{array}$ & $\mathrm{K}$, pct & $\begin{array}{l}\mathrm{Nb}, \\
\mathrm{ppm}\end{array}$ & $\begin{array}{l}\mathrm{W}^{1}, \\
\mathrm{ppm}\end{array}$ & $\begin{array}{l}\mathrm{Ge}^{2}, \\
\mathrm{ppm}\end{array}$ & & & & & \\
\hline RM24723/16 & $<2$ & 31 & 0.77 & $>2000$ & 19 & 91 & 1.15 & 2.86 & 2.74 & $>10.00$ & 0.15 & 29 & $>2000$ & $>2000$ & & & & & \\
\hline RM24725/20 & 133 & $<5$ & 0.36 & 711 & 42 & 53 & 0.69 & 6.74 & 1.40 & $>10.00$ & 0.59 & 37 & $>2000$ & $>2000$ & & & & & \\
\hline RM24726/19 & 554 & 6 & 0.25 & 915 & 136 & 90 & 0.58 & 6.20 & 1.19 & $>10.00$ & 0.73 & 52 & $>2000$ & $>2000$ & & & & & \\
\hline RM24727/18 & 50 & $<5$ & 0.97 & 469 & 18 & 137 & 0.56 & 4.41 & 2.02 & $>10.00$ & 0.30 & 23 & $>2000$ & $>2000$ & & & & & \\
\hline
\end{tabular}

\footnotetext{
${ }^{1}$ analyzed by neutron activation

2 analyzed by D.C. plasma emission

$--=$ not analyzed
} 
Appendix C. Multi-element analyses of geothermal water samples ${ }^{1}$, Fort Hamlin Hills region.

\begin{tabular}{|c|c|c|c|c|c|c|c|c|c|c|}
\hline \multirow{2}{*}{ Element } & \multirow{2}{*}{ Units } & \multicolumn{8}{|c|}{ Map Locations } & \multirow{2}{*}{$\begin{array}{c}\text { Detectior } \\
\text { Limit }\end{array}$} \\
\hline & & $\mathrm{A}$ & B-1 & $\mathrm{B}-2$ & $\mathrm{~B}-3$ & $\mathrm{C}$ & $\mathrm{D}$ & $\mathrm{F}-1$ & $\mathrm{~F}-2$ & \\
\hline Mo & $\mu \mathrm{g} / \mathrm{L}$ & $<20$ & $<20$ & 10 & 14 & $<2$ & $<2$ & $<20$ & $<20$ & 2 \\
\hline $\mathrm{Zn}$ & $\mu \mathrm{g} / \mathrm{L}$ & $<20$ & $<20$ & 8 & 780 & 14 & 4 & $<20$ & $<20$ & 2 \\
\hline $\mathrm{P}$ & $\mu \mathrm{g} / \mathrm{L}$ & $<200$ & $<200$ & 20 & 300 & 40 & 100 & $<200$ & $<200$ & 20 \\
\hline $\mathrm{Bi}$ & $\mu \mathrm{g} / \mathrm{L}$ & $<40$ & $<40$ & $<4$ & $<4$ & 4 & 20 & $<40$ & $<40$ & 4 \\
\hline $\mathrm{Cd}$ & $\mu \mathrm{g} / \mathrm{L}$ & $<10$ & $<10$ & $<1$ & $<1$ & 3 & $<1$ & $<10$ & $<10$ & 1 \\
\hline $\mathrm{Co}$ & $\mu \mathrm{g} / \mathrm{L}$ & $<20$ & $<20$ & 2 & 2 & 4 & 4 & $<20$ & $<20$ & 2 \\
\hline $\mathrm{Ni}$ & $\mu \mathrm{g} / \mathrm{L}$ & $<20$ & $<20$ & $<2$ & 4 & 4 & $<2$ & $<20$ & $<20$ & 2 \\
\hline $\mathrm{Ba}$ & $\mu \mathrm{g} / \mathrm{L}$ & $<200$ & $<200$ & $<20$ & 60 & 20 & 20 & $<200$ & $<200$ & 20 \\
\hline $\mathrm{Fe}$ & $\mathrm{mg} / \mathrm{L}$ & $<2.0$ & $<2.0$ & $<0.2$ & 2.4 & 0.6 & $<0.2$ & $<2.0$ & $<2.0$ & 0.2 \\
\hline $\mathrm{Mn}$ & $\mu \mathrm{g} / \mathrm{L}$ & $<20$ & $<20$ & 2 & 360 & 130 & 250 & $<20$ & $<20$ & 2 \\
\hline $\mathrm{Cr}$ & $\mu \mathrm{g} / \mathrm{L}$ & $<20$ & $<20$ & $<2$ & $<2$ & $<2$ & 32 & $<20$ & $<20$ & 20 \\
\hline $\mathrm{Mg}$ & $\mathrm{mg} / \mathrm{L}$ & $<2.0$ & $<2.0$ & 0.2 & 3.8 & 28 & 1.8 & $<2.0$ & $<2.0$ & .2 \\
\hline $\mathrm{V}$ & $\mu \mathrm{g} / \mathrm{L}$ & $<20$ & $<20$ & $<2$ & 12 & $<2$ & $<2$ & $<20$ & $<20$ & 2 \\
\hline $\mathrm{Al}$ & $\mathrm{mg} / \mathrm{L}$ & $<2.0$ & $<2.0$ & $<0.2$ & 0.2 & $<0.2$ & $<0.2$ & $<2.0$ & $<2.0$ & 0.2 \\
\hline $\mathrm{Be}$ & $\mu \mathrm{g} / \mathrm{L}$ & $<10$ & $<10$ & $<1$ & $<1$ & $<1$ & $<1$ & $<10$ & $<10$ & 1 \\
\hline $\mathrm{Ca}$ & $\mathrm{mg} / \mathrm{L}$ & 2.0 & 2.0 & 3.2 & 22 & 28 & 5.4 & 2.0 & 2.0 & 0.2 \\
\hline $\mathrm{Cu}$ & $\mu \mathrm{g} / \mathrm{L}$ & $<20$ & $<20$ & 4 & 290 & $<2$ & 6 & $<20$ & $<20$ & 2 \\
\hline $\mathrm{Ag}$ & $\mu \mathrm{g} / \mathrm{L}$ & $<10$ & $<10$ & $<1$ & $<1$ & $<1$ & $<1$ & $<10$ & $<10$ & 1 \\
\hline $\mathrm{Ti}$ & $\mathrm{mg} / \mathrm{L}$ & $<2.0$ & $<2.0$ & $<0.2$ & $<0.2$ & $<0.2$ & $<0.2$ & $<2.0$ & $<2.0$ & 0.2 \\
\hline $\mathrm{Sr}$ & $\mu \mathrm{g} / \mathrm{L}$ & 20 & 20 & 28 & 70 & 155 & 18 & 40 & 40 & 2 \\
\hline $\mathrm{Na}$ & $\mathrm{mg} / \mathrm{L}$ & 68 & 90 & 87 & 135 & 77 & 3.2 & 115 & 115 & 0.2 \\
\hline $\mathrm{K}$ & $\mathrm{mg} / \mathrm{L}$ & 2.0 & 2.0 & 2.0 & 1.8 & 6.4 & 2.8 & 4.0 & 4.0 & 0.2 \\
\hline
\end{tabular}

Note: No sample was taken at map location E.

${ }^{1}$ analyses by Chemex Labs, Inc., Sparks, NV, using inductively coupled plasma - atomic emission spectrography. 
Appendix D. Coordinates of sample locations.

\begin{tabular}{|c|c|c|c|c|}
\hline Map No. & Northing & Easting & Latitude & Longitude \\
\hline 1 & 7320234 & 610970 & 65.9852 & -150.556 \\
\hline 2 & 7325076 & 623381 & 66.0240 & -150.278 \\
\hline 3 & 7325280 & 624831 & 66.0253 & -150.246 \\
\hline 4 & 7325280 & 624822 & 66.0253 & -150.246 \\
\hline 5 & 7325506 & 627737 & 66.0261 & -150.182 \\
\hline 6 & 7325400 & 627972 & 66.0251 & -150.177 \\
\hline 7 & 7324394 & 629869 & 66.0153 & -150.136 \\
\hline 8 & 7324141 & 630048 & 66.0130 & -150.133 \\
\hline 9 & 7324002 & 630254 & 66.0116 & -150.128 \\
\hline 10 & 7323891 & 630465 & 66.0106 & -150.124 \\
\hline 11 & 7323990 & 630709 & 66.0114 & -150.118 \\
\hline 12 & 7324180 & 631141 & 66.0129 & -150.108 \\
\hline 13 & 7323749 & 631871 & 66.0087 & -150.093 \\
\hline 14 & 7323513 & 631862 & 66.0066 & -150.093 \\
\hline 15 & 7322136 & 633390 & 65.9936 & -150.061 \\
\hline 16 & 7319371 & 634647 & 65.9683 & -150.036 \\
\hline 17 & 7318601 & 634366 & 65.9615 & -150.043 \\
\hline 18 & 7317954 & 634713 & 65.9556 & -150.036 \\
\hline 19 & 7317233 & 634720 & 491 & -15 \\
\hline 20 & 7315951 & 635538 & 65.9373 & -150.020 \\
\hline 21 & 7315491 & 635640 & 65.9331 & -150.018 \\
\hline 22 & 7359105 & 641980 & 66.3211 & -149.831 \\
\hline 23 & 7359105 & 641980 & 66.3211 & -149.831 \\
\hline 24 & 7359111 & 641980 & 66.3211 & -149.831 \\
\hline 25 & 7359111 & 641980 & 66.3211 & -149.831 \\
\hline 26 & 735 & 641 & 66.3211 & $-14 \mathrm{C}$ \\
\hline 31 & 7359143 & 642088 & 66.3214 & -14 \\
\hline 32 & 7359143 & 642088 & 66.3214 & -149.828 \\
\hline 33 & 7359143 & 642088 & 66.3214 & -149.828 \\
\hline 34 & 7359143 & 642088 & 66.3214 & -149.828 \\
\hline 35 & 7359143 & 642088 & 66.3214 & -149.828 \\
\hline 36 & 7359143 & 642088 & 66.3214 & -149.828 \\
\hline 37 & 73 & 88 & 214 & $-14 \mathrm{C}$ \\
\hline 38 & 735 & 64 & 214 & -14 \\
\hline 39 & 7359143 & 642088 & 66.3214 & -149.828 \\
\hline 40 & 7359143 & 642088 & 66.3214 & -149.828 \\
\hline 41 & 7359143 & 642088 & 66.3214 & -149.828 \\
\hline 42 & 7323739 & 628830 & 66.0099 & -150.160 \\
\hline 43 & 7323732 & 628823 & 66.0098 & -150.160 \\
\hline 44 & 7325233 & 624766 & 66.0249 & -150.248 \\
\hline 45 & & & 66.3234 & -149.812 \\
\hline A & 7317068 & 594576 & 65.9621 & -150.919 \\
\hline B & 7320814 & 611649 & 65.9902 & -150.541 \\
\hline C & 7325466 & 625377 & 66.0267 & -150.234 \\
\hline$E$ & 7337583 & 632583 & 66.1324 & -150.063 \\
\hline $\mathrm{F}$ & 7348379 & 655184 & 66.2187 & -149.550 \\
\hline D & 7325778 & 626701 & 66.0290 & -150.205 \\
\hline coal & 7321411 & 633687 & 65.9870 & -150.055 \\
\hline coal & 7321665 & 633580 & 65.9893 & -150.057 \\
\hline coal & 7321896 & 633456 & 65.9915 & -150.060 \\
\hline
\end{tabular}

